\title{
Pharmacological Actions of Carbamate Insecticides at Mammalian Melatonin Receptors ${ }^{[}$
}

\author{
Grant C. Glatfelter, ${ }^{1,2}$ Anthony J. Jones, ${ }^{1}$ Rajendram V. Rajnarayanan, ${ }^{3}$ \\ and Margarita L. Dubocovich \\ Department of Pharmacology and Toxicology (G.C.G., A.J.J., R.V.R., M.L.D.), Interdepartmental Neuroscience Program \\ (A.J.J., M.L.D.), Jacobs School of Medicine and Biomedical Sciences, University at Buffalo, Buffalo, New York
}

Received April 22, 2020; accepted November 11, 2020

\begin{abstract}
Integrated in silico chemical clustering and melatonin receptor molecular modeling combined with in vitro $2-\left[{ }^{125} \mathrm{l}\right]$-iodomelatonin competition binding were used to identify carbamate insecticides with affinity for human melatonin receptor 1 (hMT $)_{1}$ and human melatonin receptor $2\left(\mathrm{hMT}_{2}\right)$. Saturation and kinetic binding studies with $2-\left[{ }^{125} \mathrm{l}\right]$-iodomelatonin revealed lead carbamates (carbaryl, fenobucarb, bendiocarb, carbofuran) to be orthosteric ligands with antagonist apparent efficacy at $\mathrm{hMT}_{1}$ and agonist apparent efficacy at $\mathrm{hMT}_{2}$. Furthermore, using quantitative receptor autoradiography in coronal brain slices from $\mathrm{C} 3 \mathrm{H} / \mathrm{HeN}$ mice, carbaryl, fenobucarb, and bendiocarb competed for $2-\left[{ }^{125} \mathrm{l}\right]$-iodomelatonin binding in the suprachiasmatic nucleus (SCN), paraventricular nucleus of the thalamus (PVT), and pars tuberalis (PT) with affinities similar to those determined for the $\mathrm{hMT}_{1}$ receptor. Carbaryl $(10 \mathrm{mg} / \mathrm{kg}$ i.p.) administered in vivo also competed ex vivo for $2-\left[{ }^{125} \mathrm{I}\right]$ iodomelatonin binding to the SCN, PVT, and PT, demonstrating the ability to reach brain melatonin receptors in $\mathrm{C} 3 \mathrm{H} / \mathrm{HeN}$ mice. Furthermore, the same dose of carbaryl given to $\mathrm{C} 3 \mathrm{H} / \mathrm{HeN}$ mice in constant dark for three consecutive days at subjective dusk (circadian time 10) phase-advanced circadian activity rhythms
\end{abstract}

(mean $=0.91$ hours) similar to melatonin (mean $=1.12$ hours) when compared with vehicle (mean $=0.04$ hours). Carbarylmediated phase shift of overt circadian activity rhythm onset is likely mediated via interactions with SCN melatonin receptors. Based on the pharmacological actions of carbaryl and other carbamate insecticides at melatonin receptors, exposure may modulate time-of-day information conveyed to the master biologic clock relevant to adverse health outcomes.

\section{SIGNIFICANCE STATEMENT}

In silico chemical clustering and molecular modeling in conjunction with in vitro bioassays identified several carbamate insecticides (i.e., carbaryl, carbofuran, fenobucarb, bendiocarb) as pharmacologically active orthosteric melatonin receptor 1 and 2 ligands. This work further demonstrated that carbaryl competes for melatonin receptor binding in the master biological clock (suprachiasmatic nucleus) and phase-advances overt circadian activity rhythms in $\mathrm{C} 3 \mathrm{H} / \mathrm{HeN}$ mice, supporting the relevance of circadian effects when interpreting toxicological findings related to carbamate insecticide exposure.

\section{Introduction}

Melatonin modulates melatonin receptor $1\left(\mathrm{MT}_{1}\right)$ and melatonin receptor $2\left(\mathrm{MT}_{2}\right) \mathrm{G}$ protein-coupled receptor (GPCR) signaling to regulate circadian phase and amplitude of physiological processes through action at brain (suprachiasmatic nucleus or
SCN) and peripheral (pancreas) receptors (Bothorel et al., 2002; Dubocovich and Markowska, 2005; Dubocovich et al., 2010; Peschke et al., 2013; Jockers et al., 2016; Liu et al., 2016; Karamitri and Jockers, 2019). Notably, the "hormone of darkness" and its receptors regulate circadian rhythms, metabolism, mood as well as behavior, the cardiovascular and the immune systems, and

This work was supported by Jacobs School of Medicine and Biomedical Sciences unrestricted funds (to M L D. and R V R ); National Institutes of Health

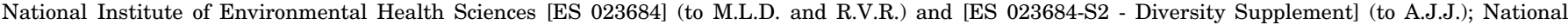

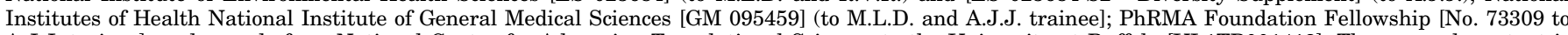

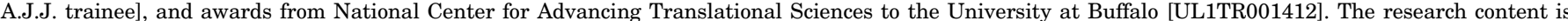

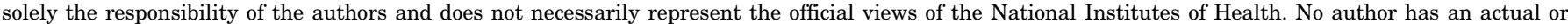
perceived conflict of interest with the contents of this article.

${ }^{1}$ G.C.G and A.J.J. contributed equally as co-first authors.

${ }^{2}$ Current affiliation: Designer Drug Research Unit, National Institute of Drug Abuse Intramural Research Program, Baltimore, Maryland

${ }^{3}$ Current affiliation: Department of Basic Sciences, Arkansas Biosciences Institute, New York Institute of Technology, Jonesboro, Arkansas.

This work has previously been presented in part as the following:

Dubocovich ML, Jones A, Popovska-Gorevski M, Glatfelter G, Mastandrea LA, and Rajnarayanan RV (2015) Melatonin receptors as targets for environmental

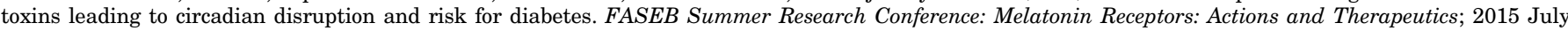

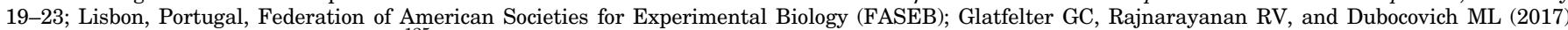

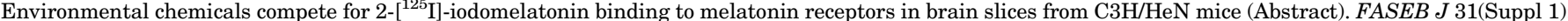

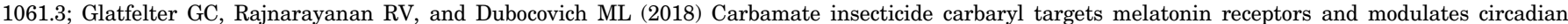

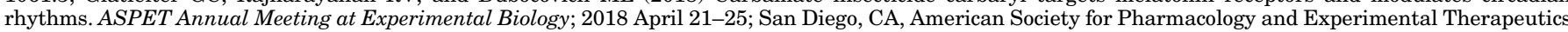

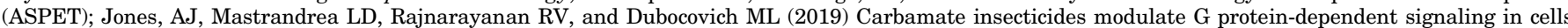

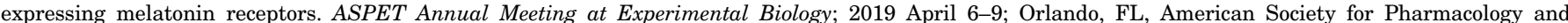

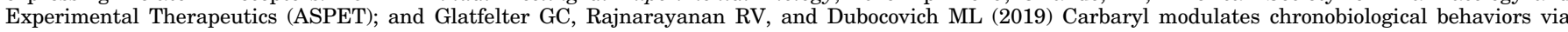
melatonin receptors (Abstract). FASEB J 33(Suppl 1):813.15.

https://doi.org/10.1124/jpet.120.000065.

S This article has supplemental material available at jpet.aspetjournals.org 
other key physiological functions (Dubocovich et al., 2010; Jockers et al., 2016; Liu et al., 2016). Circadian misalignments, or out-ofphase rhythms, are linked to increased risk for obesity, diabetes, cancer, cardiovascular disease, as well as sleep and psychiatric disorders (Baron and Reid, 2014). It follows that exposure to environmental melatonin mimics, like recently reported carbamate insecticides (Popovska-Gorevski et al., 2017), could disrupt melatonin system signaling, resulting in disturbed physiological functions and exacerbation of disease etiologies.

Current initiatives aiming to identify risks of environmental chemical exposure (Tox21; Kavlock et al., 2009; Schmidt, 2009; Tice et al., 2013) do not have measures to assess the ability of target compounds to interact with melatonin receptors and alter associated circadian or other biologic functions. Our team is optimizing an integrated in silico to in vivo pipeline approach to identify environmental circadian disruptors, specifically those that target melatonin receptors. In collaboration with other teams, our group recently used a similar strategy that was successful in identifying novel $\mathrm{MT}_{1}$ and $\mathrm{MT}_{2}$ leads (Stein et al., 2020). Furthermore, we also demonstrated that two carbamate insecticides, structurally similar to melatonin, inhibited 2-[ $\left.{ }^{125} \mathrm{I}\right]$-iodomelatonin binding to recombinant human $\mathrm{MT}_{1}\left(\mathrm{hMT}_{1}\right)$ and human $\mathrm{MT}_{2}\left(\mathrm{hMT}_{2}\right)$ melatonin receptors (Popovska-Gorevski et al., 2017), thus prompting further investigations into the pharmacological actions of these compounds at melatonin receptors mediating time-of-day messages in mammals (Dubocovich, 2007; Liu et al., 2016).

Carbamate insecticides, used industrially and domestically, are acutely toxic to insects and mammals due to reversible inhibition of acetylcholinesterase (AChE) and other esterases (Casida, 1963; Ecobichon, 2001; Moser et al., 2015b; Casida and Bryant, 2017). Use of carbaryl (1-naphthyl methylcarbamate) and other carbamates (e.g., aldicarb, bendiocarb, carbofuran, fenobucarb, fenoxycarb, methomyl, oxamyl) in agriculture as well as at home results in exposure for humans and other mammals, evidenced by trace amounts in foods, soil, as well as surface water and groundwater (Gunasekara et al., 2008; Clark-Reyna et al., 2016). Environmental and occupational exposure to carbamate insecticides has been associated with various symptoms (Whorton et al., 1979; Wyrobek et al., 1981; Meeker et al., 2004; Xia et al., 2005; Ali et al., 2015; Manyilizu et al., 2017; Bini Dhouib et al., 2016; Meyer et al., 2017) and disease pathologies (Zheng et al., 2001; Mahajan et al., 2007; Saldana et al., 2007; Montgomery et al., 2008; Slager et al., 2010; Lebov et al., 2015; Baumert et al., 2018; Patel et al., 2018; Patel and Sangeeta, 2019) related to toxicity, thought to be caused by canonical actions of carbamate insecticides on the cholinergic system. However, recent epidemiologic evidence in US farmers showed that out of 63 pesticides tested (most of which act primarily on $\mathrm{AChE}$ ), only exposure to carbamate insecticides (carbofuran and carbaryl) directly associated with sleep apnea, suggesting an ancillary mechanism of disease pathology that could involve interaction with melatonin receptors (Zirlik et al., 2013; Baumert et al., 2018). Carbamate insecticides could, therefore, influence the pathology of sleep as well as oncological, metabolic, and psychiatric disorders through pharmacological actions at melatonin receptors independent of or in addition to canonical actions at AChE.

Both increased (Tuomi et al., 2016) and decreased (Sulkava et al., 2017, 2018) melatonin receptor signaling, presumably at inappropriate times of day, is associated with increased circadian disruption-related disease risk (Schroeder and Colwell, 2013). Disruption of GPCR signaling through allosteric binding of endogenous ligands such as ions, amino acids, peptides, lipids, and autoantibodies have also been implicated in disease pathology (van der Westhuizen et al., 2015). Most, if not all, GPCRs possess allosteric binding pockets, and although functional extracellular allosteric pockets on melatonin receptors have not yet been described, recent structural data support this possibility (Stauch et al., 2020).

Our overall hypothesis was that carbamate insecticides with high structural similarity to melatonin would interact with melatonin receptors at orthosteric sites, leading to alterations of circadian phase. We first used large library pharmacoinformatic screening tools and chemical similarity cluster analyses to identify carbamate insecticides with the highest likelihood of interacting with melatonin receptors. Pharmacological interactions between common carbamate insecticides with $\mathrm{hMT}_{1}$ and $\mathrm{hMT}_{2}$ melatonin receptors, structureactivity relationships, binding mechanism(s) via docking to in silico receptor models, and in vitro competition for $2-\left[{ }^{125} \mathrm{I}\right]-$ iodomelatonin binding were then used to identify binding mechanisms via orthosteric and/or allosteric sites as well as apparent efficacy. We next tested the ability of the most potent carbamates (carbaryl, bendiocarb, fenobucarb) to compete for $2-\left[{ }^{125} \mathrm{I}\right]$-iodomelatonin binding to brain melatonin receptors in the SCN, paraventricular nucleus of the thalamus (PVT), and pars tuberalis (PT) of $\mathrm{C} 3 \mathrm{H} / \mathrm{HeN}$ mice in vitro as well as the ability of carbaryl to reach brain melatonin receptors in vivo via ex vivo quantitative receptor autoradiography. Lastly, we tested the ability of carbaryl to alter circadian phase in $\mathrm{C} 3 \mathrm{H} / \mathrm{HeN}$ mice when given at subjective dusk to determine whether carbamate exposure could modulate circadian biology in a translational mouse model.

\section{Materials and Methods}

Pharmacoinformatics and Chemical Similarity Clustering. A series of carbamate-like structures were identified using a fragmentbased query on Chem2Risk, a large pharmacoinformatics knowledge base containing more than 4 million environmental chemicals (PopovskaGorevski et al., 2017). Chemical clustering was performed using computed two-dimensional and three-dimensional Tanimoto chemical similarity indices as described earlier (Popovska-Gorevski et al., 2017).

Molecular Docking of Environmental Melatonin Ligands. Twoand three-dimensional chemical structures of melatonin and all insecticides used in this study were generated using Marvin Sketch (ChemAxon). Protein structures of $\mathrm{MT}_{1}$ and $\mathrm{MT}_{2}$ melatonin receptors were generated as described in Popovska-Gorevski et al. (2017). The SYBYL X software (Cerata, Inc., Princeton, NJ) package was used to prepare the protein and ligands for molecular docking experiments. The putative binding pockets for $\mathrm{MT}_{1}$ (inclusive of residues H195, $\mathrm{S} 110$, and $\mathrm{S} 112$ ) and for $\mathrm{MT}_{2}$ (inclusive of residues N175, H208, N268,

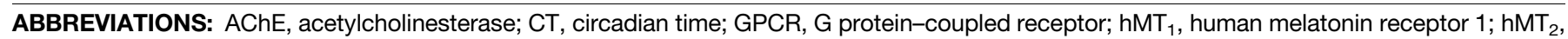

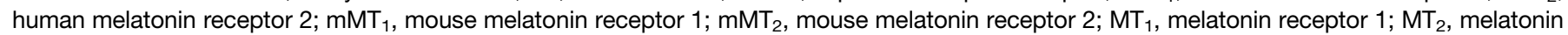

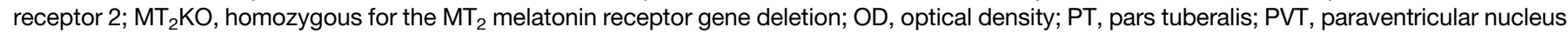

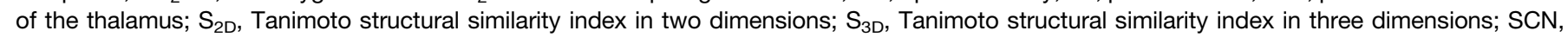
suprachiasmatic nucleus; WT, wild type; ZT, Zeitgeber time. 
and Y298) were inferred from mutagenesis data (See Tables 2 and 3 (Dubocovich et al., 2010). Surflex-Dock (SYBYL; Cerata, Inc.) and VINA (Autodock, Molecular Docking; The Scripps Research Institute) were employed to dock select environmental carbamates against human melatonin receptor models. Ligands were rendered flexible in surflex docking routine; multiple conformations (docked poses) were generated and scored using surflex score (CScore; arbitrary units), which includes a combination of Dock-score, Gold-score, PMF-score, and CHEM-score. Twenty conformations for each protein-ligand docking experiment were retrieved, and top docked poses were selected based on the orientation of the test ligand with respect to the reference ligand and its docking score. Recently, high-resolution crystal structures of $\mathrm{MT}_{1}$ in complex with agomelatine (6ME5), ramelteon (6ME2), 2-phenylmelatonin (6ME3), and 2-iodomelatonin (6ME4) and $\mathrm{MT}_{2}$ melatonin receptor in complex with ramelteon (6ME9) and 2-phenylmelatonin (6ME6) were released (Johansson et al., 2019; Stauch et al., 2019). Carbamate insecticides were docked into the binding pockets of these newly released melatonin receptors 6ME2-9 using the protocol as described above.

Cell Culture and Harvesting. The derivation of $\mathrm{CHO}$ cells stably expressing FLAG-tagged recombinant human $\mathrm{MT}_{1}$ or $\mathrm{MT}_{2}$ melatonin receptors $\left(\mathrm{CHO}_{-} \mathrm{hMT}_{1}\right.$ and $\left.\mathrm{CHO}-\mathrm{hMT}_{2}\right)$ was described previously (Gerdin et al., 2003). CHO cells were cultured in Ham's F12 media supplemented with $10 \%$ fetal calf serum, $1 \%$ HEPES, and $1 \%$ penicillin $(10,000 \mathrm{IU} / \mathrm{ml}) /$ streptomycin $(10,000 \mu \mathrm{g} / \mathrm{ml})$ in $5 \% \mathrm{CO} 2$ at $37^{\circ} \mathrm{C}$ and harvested as described previously (Popovska-Gorevski et al., 2017). Cell lines were determined to be mycoplasma-free using the LookOut Mycoplasma PCR Detection Kit (Sigma-Aldrich, St. Louis, MO). Products for cell culture were obtained from VWR International (Pittsburgh, PA). All other chemicals were reagent grade.

2-[ $\left.{ }^{125} \mathrm{I}\right]$-Iodomelatonin Binding Assays. CHO-hMT ${ }_{1}$ and CHO$\mathrm{hMT}_{2}$ cell pellets were suspended, homogenized, and washed twice by centrifugation $(12,000 \mathrm{rpm})$ in Tris-HCl buffer. Competition binding studies for selected compounds were conducted as previously described (Popovska-Gorevski et al., 2017) in active conformation buffer (50 mM Tris- $\mathrm{HCl}, 10 \mathrm{mM} \mathrm{MgCl} 2, \mathrm{pH} 7.4$ at $25^{\circ} \mathrm{C}$ ) or in resting conformation buffer (50 mM Tris-HCl, $10 \mathrm{mM} \mathrm{MgCl}_{2}, 100 \mu \mathrm{M}$ GTP, $1 \mathrm{mM}$ EDTA.Na $2,150 \mathrm{mM} \mathrm{NaCl}, \mathrm{pH} 7.4$ at $25^{\circ} \mathrm{C}$ ). Briefly, CHO-hMT or CHO-hMT $\mathrm{C}_{2}$ cell membrane suspensions [9 (7-11) and 14 (11-17) $\mu \mathrm{g}$ protein/assay $\left(95 \% \mathrm{CI}\right.$ ), respectively] were incubated with $2-\left[{ }^{125} \mathrm{I}\right]-$ iodomelatonin [75 $(66-83) \mathrm{pM}$ ] in the absence and presence of carbamate insecticides $(10 \mathrm{nM}-10 \mathrm{mM})$ or vehicle at $25^{\circ} \mathrm{C}$ ( 1 hour for

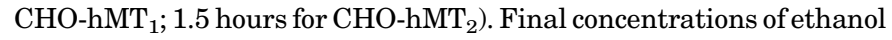
in assays for concentrations of 1 or $0.1 \mathrm{mM}$ did not exceed $4 \%$. Additional equilibrium binding assays were performed using CHO$\mathrm{hMT}_{1}$ or $\mathrm{CHO}_{-\mathrm{hMT}}$ cell membranes in active conformation buffer with titrated concentrations of $2-\left[{ }^{125} \mathrm{I}\right]$-iodomelatonin $(50-1400 \mathrm{pM})$ in the absence and presence of melatonin, luzindole, or carbaryl $(10 \mathrm{pM}-1 \mathrm{mM})$ at $25^{\circ} \mathrm{C}$ ( 1 hour for CHO-hMT 1 ; 1.5 hours for CHO$\mathrm{hMT}_{2}$ ). Further titration assays for luzindole and carbaryl binding to $\mathrm{CHO} \mathrm{hMT}_{1}$ membranes were conducted in resting buffer to prevent high-affinity $2-\left[{ }^{125} \mathrm{I}\right]$-iodomelatonin binding to the $\mathrm{G}$ protein-coupled form of the receptor. For allosteric screening dissociation assays, $2-\left[{ }^{125} \mathrm{I}\right]$-iodomelatonin $(75 \pm 4 \mathrm{pM})$ binding to membranes in resting buffer was allowed to reach equilibrium at $25^{\circ} \mathrm{C}$ ( 1 hour for CHO-hMT ; 1.5 hours for $\mathrm{CHO}^{-\mathrm{hMT}_{2}}$ ); then dissociation was initiated using $10 \mu \mathrm{M}$ melatonin in the absence or presence of vehicle, luzindole, or carbamate insecticide $(100 \mu \mathrm{M})$. After 1 hour for competition binding studies or at various time points (1-40 minutes) for dissociation assays, incubation was terminated by vacuum filtration through glass microfiber filters presoaked in $0.5 \%$ polyethyleneimine. Filters were then washed twice, and counts per minute were measured by a gamma-counter.

Animals. Male $\mathrm{C} 3 \mathrm{H} / \mathrm{HeN}$ wild-type (WT) mice from our colony and $\mathrm{C} 3 \mathrm{H} / \mathrm{HeN}$ mice homozygous for the $\mathrm{MT}_{2}$ melatonin receptor gene deletion $\left(\mathrm{MT}_{2} \mathrm{KO}\right)$ originally donated by Dr. Steven Reppert (Worcester, MA) were bred and maintained in the Laboratory of Animal Facility at University at Buffalo as previously described (Hutchinson et al., 2012). Mice were housed in a 14/10 light/dark cycle [Zeitgeber time (ZT); ZT 0: lights on $5 \mathrm{AM}$ ] in temperature $\left(22 \pm 1^{\circ} \mathrm{C}\right)-$ and humidity-controlled environments with ad libitum access to food (Harlan Teklad 2018sx) and water. Light levels were 200-300 lux at the level of the cage, and mice were housed with corncob bedding in polycarbonate translucent cages without running wheels $(30 \times 19 \mathrm{~cm})$ or with running wheels $(33 \times 15 \mathrm{~cm}$; Phenome Technologies $)$. All procedures were approved by the University at Buffalo Institutional Animal Care and Use Committee and followed National Institutes of Health guidelines. All mice for experiments in this manuscript were randomly assigned to respective treatment conditions.

Coronal Brain Slice Preparation. Preparation of coronal brain slices was adapted from previously described methods (Siuciak et al., 1990; Benloucif et al., 1997). WT and $\mathrm{MT}_{2} \mathrm{KO} \mathrm{C} 3 \mathrm{H} / \mathrm{HeN}$ mice were euthanized by decapitation between ZT 8 and ZT 10. Mouse brains were dissected, flash-frozen using 2-methylbutane, and stored at $-80^{\circ} \mathrm{C}$ until sectioning. Adjacent coronal brain sections $(20 \mu \mathrm{m})$ were cut at $-20^{\circ} \mathrm{C}$ using a cryostat (CM3050S; Leica) encompassing regions of interest (i.e., SCN, PVT, PT). Sections were immediately thaw mounted onto silane-coated slides (Azer Scientific) and stored at $-20^{\circ} \mathrm{C}$ until further use.

In Vitro Quantitative Receptor Autoradiography. Receptor autoradiography experiments were conducted as previously described (Siuciak et al., 1990; Dubocovich et al., 1998). Each C3H/HeN mouse brain provided two sets of six separate slides with six to eight adjacent sections containing SCN and PVT or PT brain regions. Slide-mounted sections stored at $-20^{\circ} \mathrm{C}$ were air-dried for 15 minutes at room temperature before incubation with various treatments during a 1-hour incubation period. Treatments all contained $2-\left[{ }^{125} \mathrm{I}\right]$-iodomelatonin (75 pM) prepared in Tris-Ca buffer (50 mM Tris- $\mathrm{HCl}$ and $4 \mathrm{mM} \mathrm{CaCl}$, $\mathrm{pH}$ 7.4) in the absence (total binding) or presence of varying concentrations $(1,10,100 \mu \mathrm{M})$ of carbaryl, bendiocarb, fenobucarb, melatonin ( $1 \mu \mathrm{M}$, positive control,nonspecific binding), or vehicle (Tris-Ca Buffer $7.7 \%$ ethanol). After incubation, slides were rinsed twice with Tris-Ca buffer (10 minutes) and rapidly rinsed in deionized water (all solutions ice cold) before being air-dried at room temperature under dim light. Slides were then pressed to x-ray film (Kodak) for 14 days before being developed (D19; Kodak). Optical densities (ODs) from autoradiograms in brain regions of interest were then measured with Image $J$ analysis software (National Institutes of Health), transformed using ${ }^{14} \mathrm{C}$ standard slides calibrated for use with ${ }^{125} \mathrm{I}$ (Miller and Zahniser, 1987), and used to determine competition for $2-\left[{ }^{125} \mathrm{I}\right]$-iodomelatonin binding across treatments (Miller and Zahniser, 1987; Masana et al., 2000). Data points are composed of averages of raw OD values obtained in two to three adjacent sections per treatment per brain region divided by the total density (treated OD value/total nontreated OD value $\times 100$ ) to yield percent total binding for each set of adjacent sections for individual mouse brains. Vehicle-treated control groups contained a minimum of $n=2-4$, whereas experimental treatment groups contained $n=4-7$, depending on the number of viable sections for each brain.

Ex Vivo Quantitative Receptor Autoradiography. Based on methods described in Beresford et al. (1998), C3H/HeN mice were treated in vivo with vehicle (corn oil, intraperitoneal) or carbaryl $(10 \mathrm{mg} / \mathrm{kg}$ i.p.) at ZT 8 . Treatments were administered at ZT 8 to avoid influence of endogenous melatonin produced in $\mathrm{C} 3 \mathrm{H} / \mathrm{HeN}$ mice (Masana et al., 2000). Carbaryl dose (10 mg/kg) and route (intraperitoneal) of administration were selected based on lack of known AChE inhibition-mediated toxic and/or behavioral effects at this dose as well as reported brain biodistribution (Declume and Benard, 1977; Albright and Simmel, 1979; Ruppert et al., 1983; Moser et al., 1988, 2012, 2015a,b; Moser, 1995; Krolski et al., 2003; Wang et al., 2014). Mice were euthanized by decapitation at $0,30,60,120$, or 240 minutes postinjection. Brains were dissected immediately and prepared for quantitative autoradiography as described (Siuciak et al., 1990; Masana et al., 2000). Brain sections from mice treated in vivo with vehicle or carbaryl were then labeled in vitro and processed for quantitative receptor autoradiography with $2-\left[{ }^{125} \mathrm{I}\right]$-iodomelatonin $(50 \mathrm{pM})$ prepared in Tris-Ca buffer (50 mM Tris- $\mathrm{HCl}$ and $4 \mathrm{mM} \mathrm{CaCl}, \mathrm{pH} 7.4)$ in 
the absence (total binding) or presence of melatonin $(1 \mu \mathrm{M})$ (nonspecific binding). Specific binding was defined by subtracting nonspecific binding values from total binding for each brain slice. Each value represents data from two to three adjacent slices from a single mouse brain. Final $n$ values for carbaryl-treated mice ranged from three to six (SCN, PVT) or two to three (PT) due to the number of viable slices in each brain assessed. Values for vehicle controls euthanized $0(n=6)$ or $240(n=4)$ postinjection were pooled for comparisons to carbaryl treatment across time (total $n=10$ ). Data represent two individual experiments used to compare competition for radioligand binding ex vivo across treatment time points.

Carbaryl-Mediated Phase Shift of Circadian Running Wheel Activity Onset. Methods are previously described in Benloucif and Dubocovich (1996) and Dubocovich et al. (1998), (2005). Briefly, male $\mathrm{C} 3 \mathrm{H} / \mathrm{HeN}$ mice were housed in constant darkness for 2 weeks before treatment to establish stable free-running circadian rhythms of running wheel activity. Vehicle (saline/15\% ethanol), carbaryl (10 mg/kg i.p.), or melatonin ( $3 \mathrm{mg} / \mathrm{kg}$, s.c.) treatments were given for three consecutive days at approximately circadian time (CT) 10 (CT 12 = onset of running wheel activity; CT $10=2$ hours onset of circadian rhythm of wheel-running activity or subjective dusk). Times of treatments were determined from actograms by predicted onset of running wheel activity for each mouse based on stable free-running activity rhythm onsets for 7-12 days before treatments and were centered around CT 10, occurring from CT 9 to CT 11 (average time of injections was CT 10.1-10.2, respectively, for days 1-3). Injections and animal care in constant dark were done by dim red light $(<5$ lux $)$ to avoid influence of light on circadian running wheel activity rhythms (Benloucif and Dubocovich, 1996; Benloucif et al., 1999). The shift in time of post-treatment activity rhythm onset fits of 7-12 days were compared with pretreatment onset fits on the first day after treatment to determine phase shift values. An earlier onset in the post-treatment onsets relative to pretreatment onsets is considered a phase-advance, whereas the opposite would be a phase-delay in activity rhythms. Actograms were analyzed blind to treatment and were excluded before analyses if mice displayed tau changes greater than 0.3 or low activity or if two thirds of the injections occurred outside the target window. Only one mouse was excluded based on the aforementioned criteria from the carbaryl treatment group for having two thirds of the injections fall outside the acceptable time window. Negative (vehicle: $n=7$ ) and positive (melatonin: $n=4$ ) controls were compared with carbaryl-treated mice $(n=12)$ to assess effects of treatment on magnitude of phase changes post-treatment. Data were replicated in two separate experiments (experiment $1: n=3$ vehicle, $n=$ 5 carbaryl; experiment 2: $n=4$ vehicle, $n=8$ carbaryl, $n=4$ melatonin) pooled together for statistical analysis (total $n=24$ individual mice).

Reagents. 2-[ $\left.{ }^{125} \mathrm{I}\right]$-iodomelatonin (Specific Activity: $2200 \mathrm{ci}, 81.4$ $\mathrm{TBq} / \mathrm{mmol}$ ) was purchased from Perkin Elmer (Shelton, CT). Guanosine 5 '-triphosphate sodium salt hydrate (GTP), melatonin, aldicarb, bendiocarb, carbaryl, carbofuran, fenobucarb, fenoxycarb, methomyl, oxamyl, and corn oil were obtained from Sigma-Aldrich. Luzindole was purchased from Tocris (Minneapolis, MN).

Compound and Drug Preparation. For in vitro experiments, melatonin and luzindole (13 mM stock solutions) as well as aldicarb, bendiocarb, carbaryl, and fenobucarb ( $130 \mathrm{mM}$ stock solutions) were prepared in ethanol and subsequently diluted $1 / 10$ in 50\% ethanol/50\% Tris-HCl buffer $\left(50,10 \mathrm{mM} \mathrm{MgCl}_{2}, \mathrm{pH} 7.4\right.$ at $\left.25^{\circ} \mathrm{C}\right)$. Fenoxycarb (130 and $13 \mathrm{mM}$ ) was made in $100 \%$ ethanol and next diluted $1 / 10$ in $50 \%$ ethanol/50\% Tris-HCl buffer. Methomyl and oxamyl (130 mM stock solutions) were dissolved in water. All subsequent dilutions were performed in Tris-HCl buffer.

For ex vivo binding studies, carbaryl was dissolved in corn oil $(1 \mathrm{mg} / \mathrm{ml})$ at $37^{\circ} \mathrm{C}$ and administered at $0.01 \mathrm{ml} / \mathrm{g}$ mouse body weight for a dose of $10 \mathrm{mg} / \mathrm{kg}$ (i.p.). For phase shift experiments, carbaryl was dissolved in $100 \%$ ethanol and diluted in sterile saline to $1 \mathrm{mg} / \mathrm{ml}$ in $15 \%$ ethanol under continuous sonication and administered at $0.01 \mathrm{ml} / \mathrm{g}$ mouse body weight for a dose of $10 \mathrm{mg} / \mathrm{kg}$ (i.p.). Melatonin $(0.9 \mathrm{mg} / \mathrm{ml})$ was dissolved in vehicle and administered at $0.1 \mathrm{ml} / 30 \mathrm{~g}$ mouse body weight for a dose of $3 \mathrm{mg} / \mathrm{kg}$ s.c. similar to as previously described (Dubocovich et al., 2005).
Data Analysis and Statistics. All data analyses were done using GraphPad Prism 8 software (La Jolla, CA). For in vitro binding studies, counts per minute were converted to percent total binding, with $100 \%$ defined as uninhibited $2-\left[{ }^{125} \mathrm{I}\right]$-iodomelatonin binding and with $0 \%$ being nonspecific binding (NS) for each experiment. Concentration-response curves were fit to competition binding data using the equation "Y = Bottom + (Top - Bottom $) /\left(1+10_{50}^{\emptyset \mathrm{X}-\mathrm{LogEC}}\right)$ " (Slope $=1$ ). Dissociation curves were fit to kinetic binding data using the equation "Y $=\left(\mathrm{Y}_{0}-\mathrm{NS}\right) \times \mathrm{e}^{(-\mathrm{Koff} \times \mathrm{X})}+\mathrm{NS}$." Top constraints were set to "100\%" for all in vitro binding experiments. For structureactivity relationship and GTP shift competition binding studies, curve bottoms were constrained to " $0 \%$." Bottoms of curves were constrained to be "greater than 0 " for binding titration and dissociation assays. For in vitro quantitative receptor autoradiography experiments curve bottoms were constrained to nonspecific binding values determined for each set of adjacent sections analyzed. Individual $\mathrm{K}_{\mathrm{i}}, \mathrm{K}_{\mathrm{B}}$, and $\alpha$ values were calculated using commercial software (GraphPad Prism) according to the Cheng-Prusoff equation (Cheng and Prusoff, 1973; Lazareno and Birdsall, 1995). $\mathrm{K}_{\mathrm{D}}$ values used in calculations correspond to specific receptors and conformation in buffer hMT $_{1}$ active: $116 \mathrm{pM}$; $\mathrm{hMT}_{1}$ resting: $280 \mathrm{pM} ; \mathrm{hMT}_{2}$ active: $119 \mathrm{pM} ; \mathrm{hMT}_{2}$ resting: $215 \mathrm{pM}$ ). $2-\left[{ }^{125} \mathrm{I}\right]$-iodomelatonin dissociation rates $\left(\mathrm{K}_{\mathrm{off}}\right)$ in the presence of test compounds are compared with vehicle using a Friedman test (alpha $=0.05$ ) with Dunn's post-test for multiple comparisons $($ alpha $=0.05)$. Significant differences between $\mathrm{pK}_{\mathrm{i}(\mathrm{GTP})}$ and $\mathrm{pK}_{\mathrm{i}(\mathrm{Control})}$ were determined by two-tailed paired $t$ tests (alpha $=0.05$ ). Apparent efficacy at melatonin receptors of compounds was assessed by subtracting $\mathrm{pK}_{\mathrm{i}}$ values obtained in active buffer from resting buffer $\left(\mathrm{pK}_{\mathrm{i}(\mathrm{GTP})}\right.$ $\left.-\mathrm{pK}_{\mathrm{i}(\text { Control })}=\Delta \mathrm{pK}_{\mathrm{i}}\right)$ and comparison melatonin $\Delta \mathrm{pK}_{\mathrm{i}}\left(\mathrm{CHO}-\mathrm{hMT}_{1}\right.$ : 1.19; $\mathrm{CHO}^{-\mathrm{hMT}_{2}}$ : 0.41). Affinity shifts or lack thereof between active and resting buffers indicate apparent efficacy (Lefkowitz et al., 1976; Nonno et al., 1998); thus, ligands were characterized as agonists $\left(\Delta \mathrm{pK}_{\mathrm{i}}>\right.$ $20 \%$ melatonin), antagonists $\left(\Delta \mathrm{pK}_{\mathrm{i}}<20 \%\right.$ melatonin, $>-20 \%$ melatonin), or inverse agonists $\left(\Delta \mathrm{pK}_{\mathrm{i}}<-20 \%\right.$ melatonin) accordingly. $\mathrm{K}_{D}$ used to determine $\mathrm{IC}_{50}$ for in vitro quantitative receptor autoradiography experiments was $87.3 \mathrm{pM}$ (unpublished data). For in vitro and ex vivo quantitative receptor autoradiography data, average values for each treatment condition were compared with the control group (vehicletreated) using one-way ANOVA (alpha $=0.05$ ) with a Dunnett's post-test (alpha $=0.05$ ) to assess differences between groups. For in vivo circadian rhythm experiments, circadian phase changes were compared via oneway ANOVA (alpha $=0.05)$ with a Dunnett's post-test (alpha $=0.05)$ comparing carbaryl and melatonin to vehicle-treated mice.

\section{Results}

Chemical Clustering of Carbamate Insecticides. A search for a carbamate functional group in the Chem2Risk knowledge base resulted in the identification of eight carbamate insecticides (Fig. 1A). In addition to carbaryl and carbofuran, which were previously identified as structurally similar to melatonin (Popovska-Gorevski et al., 2017), carbamate insecticides fenobucarb, fenoxycarb, and bendiocarb cluster together with normalized Tanimoto structural similarity indices in two dimensions $\left(\mathrm{S}_{2 \mathrm{D}}\right)$ and three dimensions $\left(\mathrm{S}_{3 \mathrm{D}}\right)$ in the range 0.4-0.6 (cluster 1; Fig. 1B). Interestingly, all the carbamate insecticides in cluster 1 contain at least one aromatic ring system and a carbamate $(-\mathrm{N}-\mathrm{C}(=\mathrm{O})-)$ moiety, which aligns well with the melatonin pharmacophore. The carbamate insecticides aldicarb, methomyl, and oxamyl clustered together with very low structural similarly with $\mathrm{S}_{2 \mathrm{D}}$ and $\mathrm{S}_{3 \mathrm{D}}<0.4$ (cluster 2; Fig. 1B).

Molecular Docking of Carbamate Insecticides to $\mathbf{h M T}_{\mathbf{1}}$ and $\mathbf{h M T}_{\mathbf{2}}$ Receptors. Melatonin and the carbamate insecticides were docked into the putative melatonin binding pockets in $\mathrm{hMT}_{1}$ and $\mathrm{hMT}_{2}$ receptor models. Cluster 1 carbamate insecticides (carbaryl, carbofuran, bendiocarb, fenobucarb, and 
A<smiles>COc1ccc2[nH]cc(CCCNC(C)=O)c2c1</smiles>

Melatonin<smiles>CNC(=O)Oc1cccc2ccccc12</smiles>

Carbaryl<smiles>CCC(C)c1ccccc1OC(=O)NC</smiles>

Fenobucarb<smiles>CCOC(=O)NCCOc1ccc(Oc2ccccc2)cc1</smiles>

Fenoxycarb<smiles>CNC(=O)ON=C(SC)C(=O)N(C)C</smiles>

Oxamyl

\section{Bendiocarb}<smiles>CNC(=O)ON=CC(C)(C)SC</smiles>

Aldicarb

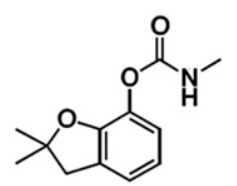

Carbofuran

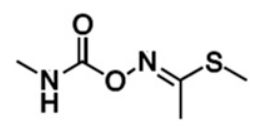

Methomyl

B

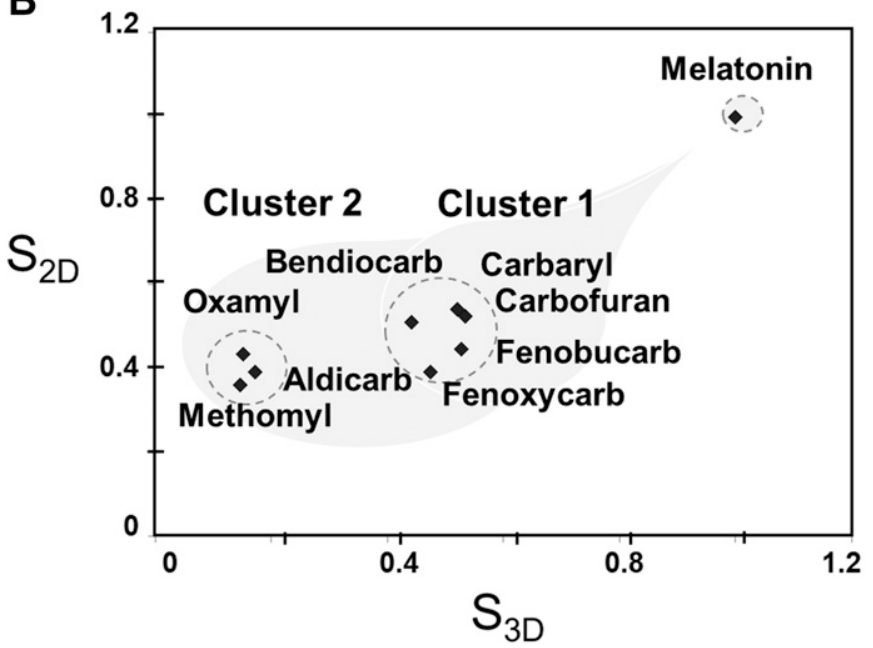

Fig. 1. Structural similarity clustering of melatonin and carbamates. (A) Structures of melatonin and carbamates. (B) The carbamate insecticides carbaryl, carbofuran, bendiocarb, fenoxycarb, and fenobucarb cluster together and are structurally similar to melatonin. Normalized Tanimoto index of chemical similarity in two and three dimensions are indicated as $S_{2 D}$ and $\mathrm{S}_{3 \mathrm{D}}$, respectively.

fenoxycarb) dock into the putative melatonin binding site with $\mathrm{H} 195$ (in $\mathrm{hMT}_{1}$ ) or $\mathrm{H} 208$ (in $\mathrm{hMT}_{2}$ ) within 2 to $3 \AA$, similar to melatonin (Fig. 2). Surflex docking experiments with cluster 1 carbamates yielding at least five docked poses per receptorligand complex, where the ligand was positioned into the putative binding pocket, were chosen for further analysis. Surflex docking scores of top ligand-hMT $\mathrm{h}_{2}$ receptor complexes were melatonin (11.6; Fig. $2 \mathrm{G})>$ carbaryl $(9.2$; Fig. $2 \mathrm{H})>$ fenobucarb (8.9; Fig. 2K) $>$ bendiocarb (8.5; Fig. 2I) $>$ carbofuran (8.1; Fig. 2L) $>$ fenoxycarb (7.8; Fig. 2J), whereas the corresponding scores for the ligand-hMT $\mathrm{MT}_{1}$ complexes were melatonin (11.9; Fig. 2A) $>$ fenobucarb (7.1; Fig. 2E) $>$ carbaryl (7.0; Fig. 2B) $>$ bendiocarb (5.6; Fig. 2C) $>$ carbofuran (5.1; Fig. 2F) $>$ fenoxycarb (4.7; Fig. 2D). Root mean square deviation of the top five binding poses for each ligand-receptor complexes was $<2.0 \AA$ A. Autodock

binding affinities of cluster 1 carbamate- $\mathrm{MT}_{2}$ complexes were in the range -4 to $-8 \mathrm{kcal} / \mathrm{mol}$ compared with $-11.5 \mathrm{kcal} / \mathrm{mol}$ for melatonin- $\mathrm{MT}_{2}$ complex consistent with the results of surflex docking scores. Based on these results, cluster 1 carbamates were predicted to mimic melatonin actions at $\mathrm{MT}_{1}$ and $\mathrm{MT}_{2}$ receptors and were propagated for further validation using receptor binding in vitro.

The recent availability of high-resolution x-ray crystal structures of melatonin receptors in complex with agomelatine, ramelteon, 2-iodomelatonin, and 2-phenylmelatonin (Johansson et al., 2019; Stauch et al., 2019), after completion of the entire in silico to in vivo Chem2Risk pipeline, warranted a comparative analysis of the protein structures. A closer look at the ramelteon bound complexes reveals that it makes hydrogen binding contact with the amino acid residue Q181 and various nonbinding contacts with A104, M107, G108, N162, L168, T178, F179, $\mathrm{T} 188, \mathrm{~V} 191$, and $\mathrm{L} 254$ in the $\mathrm{MT}_{1}$ melatonin receptor complex (Protein Data Bank identifier: $6 \mathrm{ME2}$; $\mathrm{MT}_{1}$-CC-ramelteon; Stauch et al., 2019) and that in $\mathrm{MT}_{2}$ melatonin receptor complex it makes hydrogen binding contact with $\mathrm{N} 175$ and various nonbonding contacts with A117, M120, G121, V124, I125, L181, T191, F192, Q194, Y200, V204, V205, L267, N268, and G271 (Protein Data Bank identifier: 6ME9; $\mathrm{MT}_{2}$-CCramelteon; Johansson et al., 2019). Docking of the top-scoring carbamate, carbaryl, into ramelteon binding pockets in $\mathrm{hMT}_{1}$ and $\mathrm{hMT}_{2}$ models derived from these crystal structures show considerable overlap of binding pocket residues between the models used in our computational pipeline and the carbamatemelatonin receptor complexes generated using the x-ray crystal structures 6ME2-9. Top carbaryl-MT ${ }_{1}$ docked poses indicate potential hydrogen bonding interactions at $\mathrm{Q} 181$ of $\mathrm{hMT}_{1}$, like ramelteon (Supplemental Fig. 1A), and at N175 or Q194 of $\mathrm{hMT}_{2}$ (Supplemental Fig. 1B). The residues N175 and H208 were within the $4 \AA$ zone of the bound ligand carbaryl in $\mathrm{MT}_{2}$ complexes, consistent with our previously published model (Popovska-Gorevski et al., 2017).

Competition of Carbamate Insecticides for 2-[ $\left.{ }^{125} \mathrm{I}\right]-$ Iodomelatonin Binding to $\mathbf{h M T}_{1}$ and $\mathbf{h M T}_{2}$ Melatonin Receptors. Affinities for carbaryl, carbofuran, fenobucarb, fenoxycarb, bendiocarb, aldicarb, methomyl, and oxamyl (Fig. 3) were determined by assessing competition for 2 - $\left[{ }^{125} \mathrm{I}\right]$-iodomelatonin binding $(75 \mathrm{pM})$ at $\mathrm{hMT}_{1}$ and $\mathrm{hMT}_{2}$ stably expressed in $\mathrm{CHO}$ cell membranes. All eight carbamates competed for $2-\left[{ }^{125} \mathrm{I}\right]$-iodomelatonin binding at $\mathrm{hMT}_{1}$ $\left(\mathrm{K}_{\mathrm{i}}\right.$ range $\left.=3.34-1070 \mu \mathrm{M}\right)$ and $\mathrm{hMT}_{2}\left(\mathrm{~K}_{\mathrm{i}}\right.$ range $=0.163-438 \mu \mathrm{M}$; Fig. 3 ; Table 1 ). Affinity constants ( $\mathrm{K}_{\mathrm{i}}$ values) for all compounds tested derived from competition with $2-\left[{ }^{125} \mathrm{I}\right]$-iodomelatonin are listed in Table 1. Aldicarb, carbofuran, carbaryl, fenobucarb, bendiocarb, oxamyl, methomyl, and fenoxycarb displayed 55-, 26-, 20-, 18-, 14-, 2.6-, 2.4-, and 1.1-fold selectivity for competition binding at $\mathrm{hMT}_{2}$ compared with $\mathrm{hMT}_{1}$ (Table 1), respectively. Rank order of affinities for competition binding of carbamate insecticides at $\mathrm{hMT}_{1}$ is carbaryl $>$ fenobucarb $>$ fenoxycarb $>$ bendiocarb $>$ carbofuran $>$ oxamyl $>$ aldicarb $>$ methomyl and at $\mathrm{hMT}_{2}$ is carbaryl $>$ fenobucarb $>$ bendiocarb $>$ carbofuran $>$ aldicarb $>$ fenoxycarb $>$ oxamyl $>$ methomyl (Table 1).

Binding Mechanism(s) of Carbamate Insecticide for $\mathbf{h M T}_{1}$ and $\mathbf{h M T}_{2}$ Melatonin Receptors. Next, we determined the mode of binding (i.e., orthosteric vs. allosteric) of carbamate insecticides to the $\mathrm{hMT}_{1}$ and $\mathrm{hMT}_{2}$ melatonin receptors. Binding cooperativity factors $(\alpha)$ of melatonin, 


\section{$\mathrm{hMT}_{1}$ Melatonin Receptor}
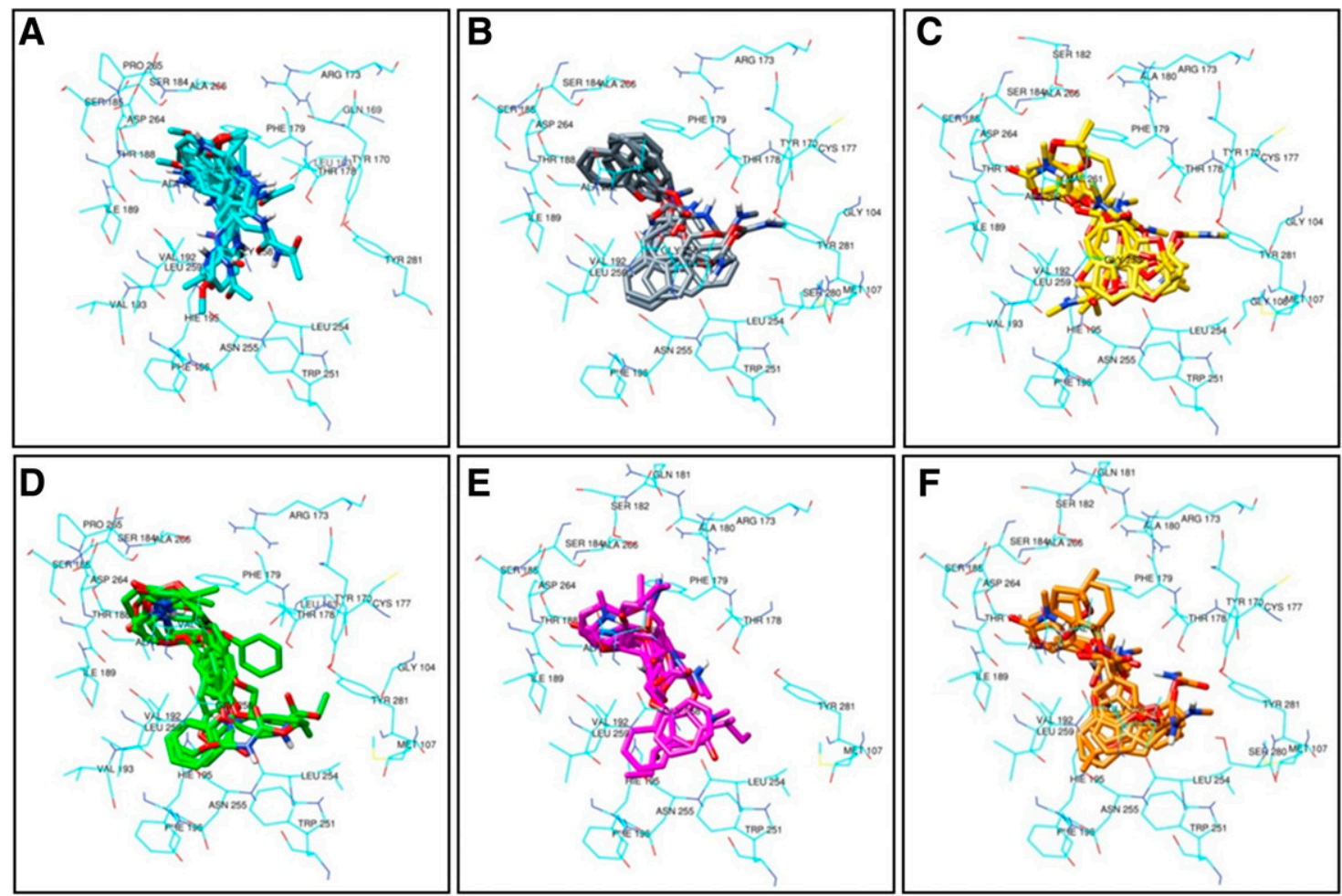

\section{$\mathrm{hMT}_{2}$ Melatonin Receptor}
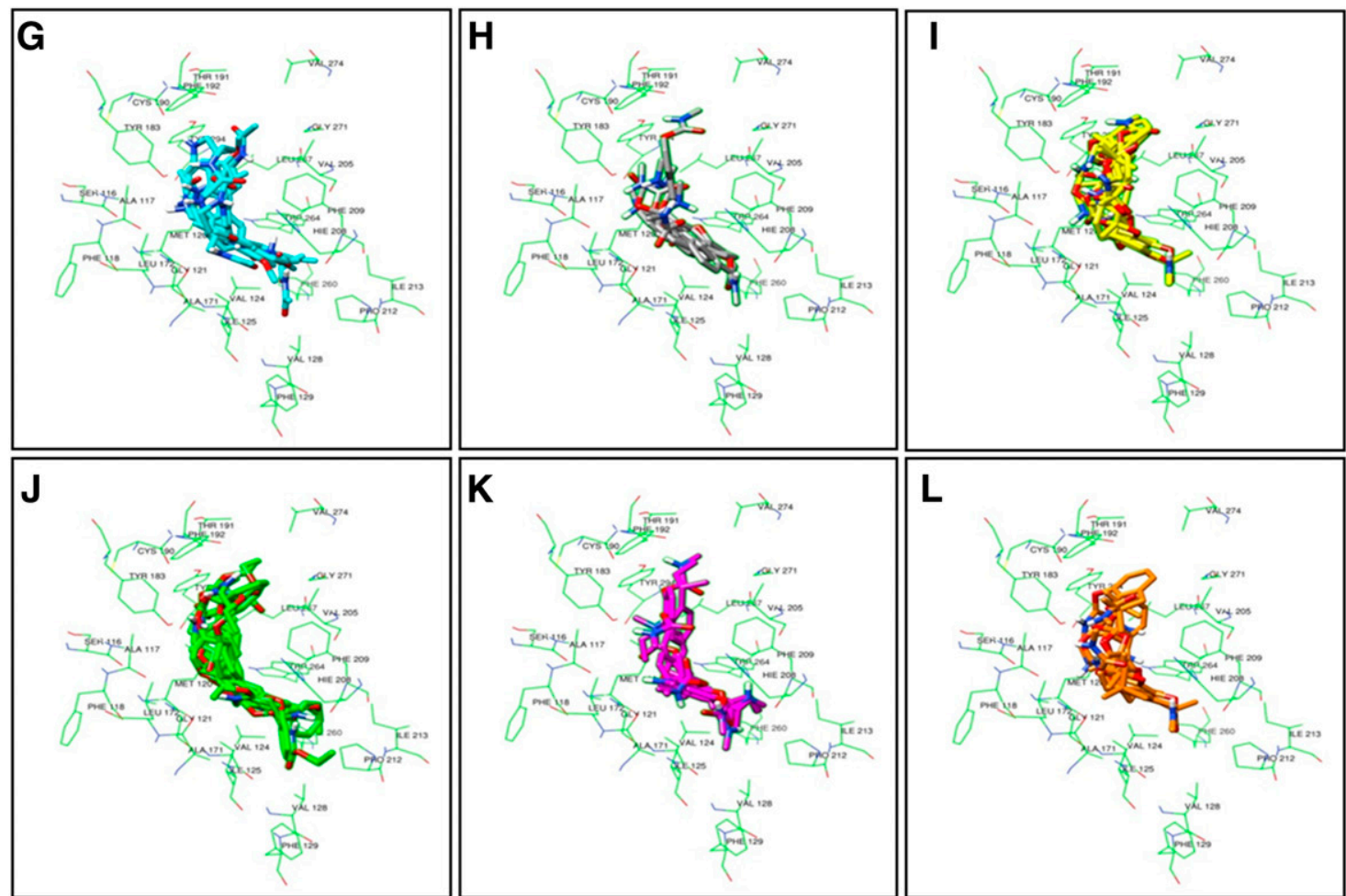

Fig. 2. Molecular docking of melatonin and carbamate insecticides with human $\mathrm{MT}_{1}$ and $\mathrm{MT}_{2}$ melatonin receptors. Top docking poses of melatonin (rendered in blue) (A), carbaryl (gray) (B), bendiocarb (yellow) (C), fenoxycarb (green) (D), fenobucarb (magenta) (E), and carbofuran (orange) (F) with human $\mathrm{MT}_{1}$ melatonin receptor. Cluster 1 carbamate insecticides $(\mathrm{B}-\mathrm{F})$ were able to bind to the putative melatonin binding pocket, similar to the cognate ligand melatonin (A). (G-L) Molecular docking of melatonin and carbamate insecticides with human $\mathrm{MT}_{2}$ melatonin receptor. Top docking poses of melatonin (rendered in blue) $(\mathrm{G})$, carbaryl (gray) $(\mathrm{H})$, bendiocarb (yellow) (I), fenoxycarb (green) (J), fenobucarb (magenta) (K), and carbofuran (orange) (L) with human $\mathrm{MT}_{1}$ melatonin receptor. Cluster 1 carbamate insecticides $(\mathrm{H}-\mathrm{L}$ ) were able to bind to the putative melatonin binding pocket, similar to the cognate ligand melatonin $(\mathrm{G})$. 


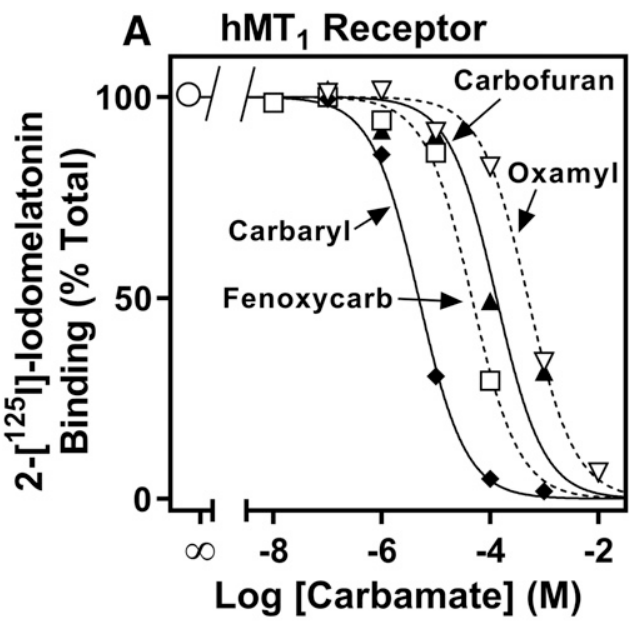

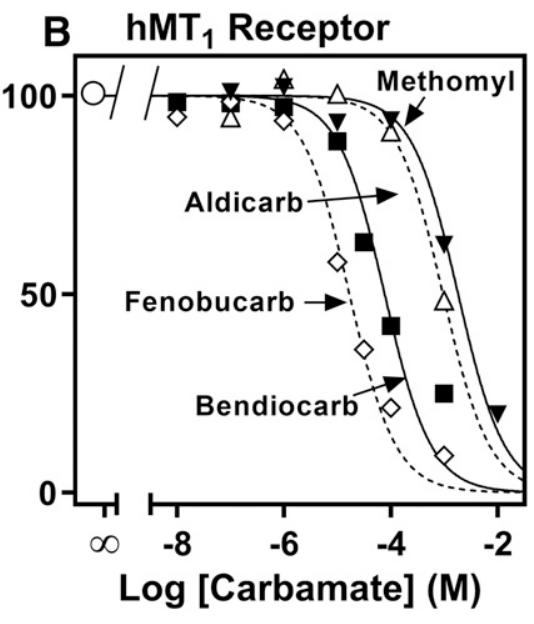

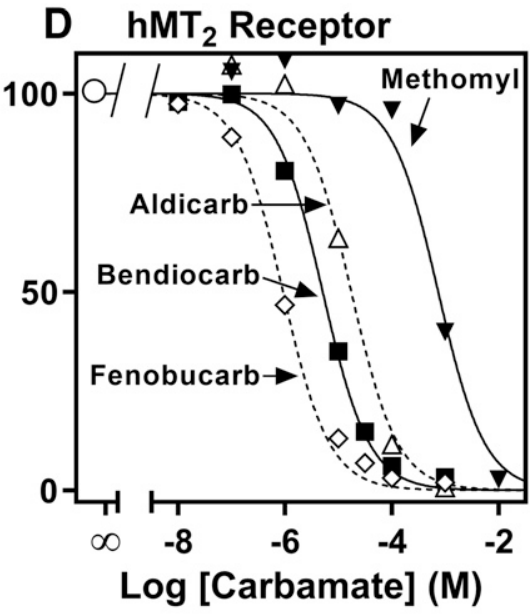

Fig. 3. Carbamate insecticides compete for $2-\left[{ }^{125} \mathrm{I}\right]$-iodomelatonin binding to $\mathrm{hMT}_{1}$ and $\mathrm{hMT}_{2}$ melatonin receptors. The ordinate represents $2-\left[{ }^{125} \mathrm{I}\right]$-iodomelatonin $\left(2-\left[{ }^{125} \mathrm{I}\right]-\mathrm{MLT}\right)$ binding expressed as percent total binding. Membranes from $\mathrm{CHO}$ cells stably expressing $\mathrm{hMT}_{1}(\mathrm{~A}$ and $\mathrm{B})$ or $\mathrm{hMT}_{2}$ (C and $\left.\mathrm{D}\right)$ melatonin receptors were incubated with $2-\left[{ }^{125} \mathrm{I}\right]$-iodomelatonin (75 pM) in the absence $(\bigcirc)$ and the presence of various concentrations of ligands: carbaryl $(\downarrow)$, fenoxycarb $(\square)$, and carbofuran $(\boldsymbol{\Delta})$ (A and C); fenobucarb $(\diamond)$, bendiocarb $(\square)$, and aldicarb $(\triangle)(B$ and D). Symbols shown are the mean from representative experiments independently repeated three to eight times. See Table 1 for derived affinity constants. luzindole (a nonselective $\mathrm{MT}_{1} / \mathrm{MT}_{2}$ competitive receptor antagonist/inverse agonist), and carbaryl were derived from determining the maximal fractional inhibition (MFI) of 2 - $\left[{ }^{125} \mathrm{I}\right]$-iodomelatonin binding at five different radioligand concentrations $(30-1400 \mathrm{pM})$ to $\mathrm{CHO}^{-\mathrm{hMT}_{1}}$ and $\mathrm{CHO} \mathrm{hMT}_{2}$ membranes (Supplemental Table 1). For both $\mathrm{hMT}_{1}$ and $\mathrm{hMT}_{2}$ receptors, melatonin $\left(\mathrm{hMT}_{1} \mathrm{~K}_{\mathrm{B}}=0.220 \mathrm{nM}\right.$, Supplemental Fig. 2A; hMT ${ }_{2} \mathrm{~K}_{\mathrm{B}}=0.124 \mathrm{nM}$, Supplemental
Fig. 2B) completely inhibited binding $\left(\mathrm{hMT}_{1}\right.$ and $\mathrm{hMT}_{2} \alpha<0.001$, Supplemental Fig. 2, A and B) of saturating concentrations of radioligand confirming both melatonin and $2-\left[{ }^{125} \mathrm{I}\right]$-iodomelatonin bind to the same site. Luzindole $\left(\mathrm{K}_{\mathrm{B}}=13.8 \mathrm{nM}, \alpha<0.001\right.$, Supplemental Fig. 2D) and carbaryl $\left(\mathrm{K}_{\mathrm{B}}=453 \mathrm{nM}, \alpha<0.001\right.$, Fig. 4B), also completely inhibited over 1000 pM 2-[ $\left.{ }^{125} \mathrm{I}\right]-$ iodomelatonin binding at $\mathrm{hMT}_{2}$ indicating that they bind to the orthosteric site. Interestingly, for luzindole $\left(\mathrm{K}_{\mathrm{B}}=387 \mathrm{nM}\right.$,

TABLE 1

Competition of carbamate insecticides for 2-[ $\left.{ }^{125} \mathrm{I}\right]$-iodomelatonin binding to $\mathrm{hMT}_{1}$ or $\mathrm{hMT}_{2}$ melatonin receptors expressed in CHO cells

Competition of various carbamates insecticides $(10 \mathrm{nM}-10 \mathrm{mM})$ for $2-\left[{ }^{125} \mathrm{I}\right]$-iodomelatonin $(75 \mathrm{pM})$ binding to $\mathrm{hMT}_{1}$ or hMT $\mathrm{helatonin}_{2}$ receptors stably expressed in CHO cells. pKi values were calculated from $\mathrm{IC}_{50}$ values obtained from competition curves (see Fig. 3 ) by the method of Cheng and Prusoff (1973). Shown are mean pKi values and 95\% confidence intervals of at least three independent determinations. $\mathrm{K}_{\mathrm{i}}$ ratios represent fold difference $\left(\mathrm{K}_{\mathrm{i}(\mathrm{hMT} 1} / \mathrm{K}_{\mathrm{i}(\mathrm{hMT} 2)}\right)$ in affinity of each carbamate insecticide for hMT $\mathrm{T}_{1}$ and $\mathrm{hMT}_{2}$ melatonin receptors. $\mathrm{pK}_{\mathrm{i}}$ values for melatonin are 9.84 $(95 \% \mathrm{CI}=9.55-10.14 ; n=5)$ at the $\mathrm{hMT}_{1}$ and $9.65(95 \% \mathrm{CI}=9.53-9.76 ; n=5)$ at the $\mathrm{hMT}_{2}\left(\mathrm{~K}_{\mathrm{i}(\mathrm{hMT} 1)} / \mathrm{K}_{\mathrm{i}(\mathrm{hMT} 2)}=0.70\right)$.

\begin{tabular}{|c|c|c|c|c|c|}
\hline \multirow{3}{*}{ Ligand } & \multicolumn{5}{|c|}{ Ligand competition for $2-\left[{ }^{125} \mathrm{I}\right]$-iodomelatonin binding } \\
\hline & \multicolumn{2}{|c|}{ Human $\mathrm{MT}_{1}$} & \multicolumn{2}{|c|}{ Human $\mathrm{MT}_{2}$} & \multirow{2}{*}{$\begin{array}{c}\text { Ratio } \\
\mathrm{K}_{\mathrm{i} \text { hMT1 } 1} / \mathrm{K}_{\mathrm{i} \text { hMT2 }}\end{array}$} \\
\hline & $\mathrm{pK}_{\mathrm{i}}$ & $n$ & $\mathrm{pK}_{\mathrm{i}}$ & $n$ & \\
\hline Carbaryl & $5.52(5.29-5.75)$ & 6 & $6.81(6.65-6.96)$ & 6 & 20 \\
\hline Fenobucarb & $5.01(4.89-5.13)$ & 6 & $6.27(6.16-6.38)$ & 6 & 18 \\
\hline Fenoxycarb & $4.53(4.41-4.66)$ & 8 & $4.55(4.40-4.70)$ & 5 & 1.1 \\
\hline Bendiocarb & $4.38(4.30-4.45)$ & 5 & $5.53(5.40-5.67)$ & 6 & 14 \\
\hline Carbofuran & $4.03(3.91-4.14)$ & 3 & $5.46(5.12-5.80)$ & 3 & 26 \\
\hline Oxamyl & $3.59(3.04-4.15)$ & 3 & $3.99(3.60-4.48)$ & 3 & 2.6 \\
\hline Aldicarb & $3.29(2.88-3.70)$ & 3 & $5.01(4.90-5.12)$ & 3 & 55 \\
\hline Methomyl & $3.01(2.43-3.60)$ & 3 & $3.38(2.96-3.81)$ & 3 & 2.4 \\
\hline
\end{tabular}



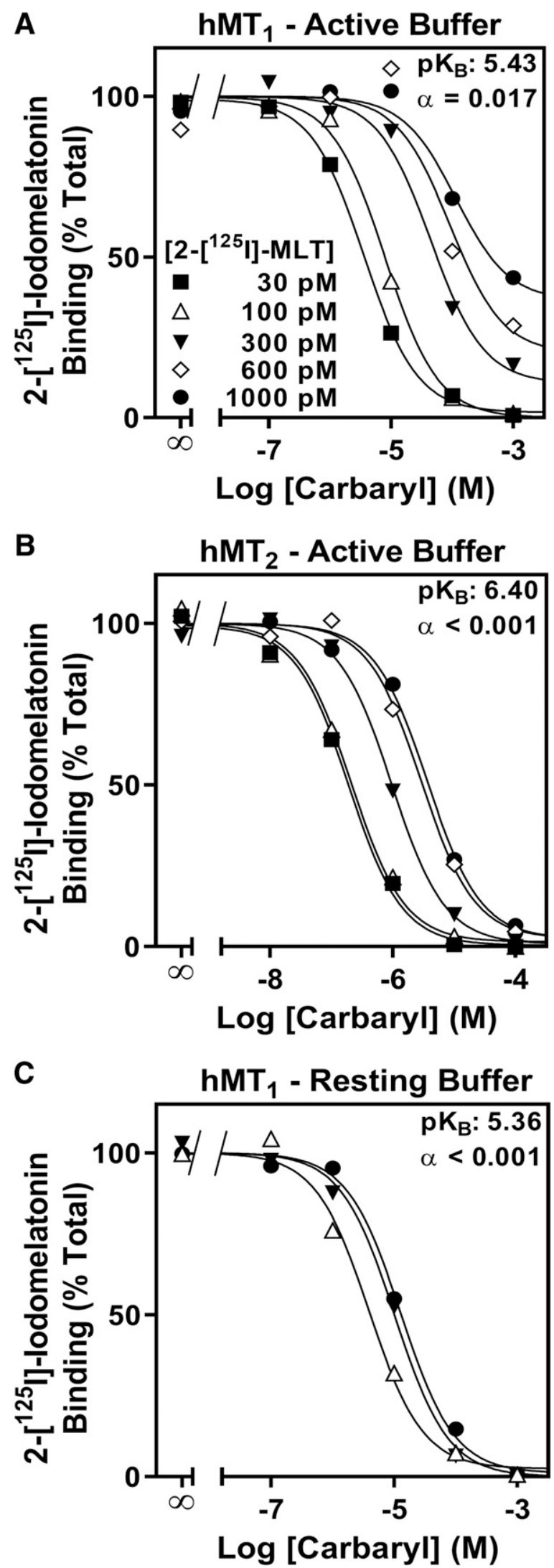

Fig. 4. Carbaryl binds to melatonin receptor orthosteric sites. The ordinates represent $2-\left[{ }^{125} \mathrm{~T}\right]$-iodomelatonin $\left(2-\left[{ }^{125} \mathrm{I}\right]-\mathrm{MLT}\right)$ binding expressed as percent total $2-\left[{ }^{125} \mathrm{I}\right]$-iodomelatonin binding to membranes from CHO cells stably expressing $\mathrm{hMT}_{1}\left(\mathrm{~A}\right.$ and $\mathrm{C}$ ) or $\mathrm{hMT}_{2}(\mathrm{~B})$ melatonin receptors. Membranes were incubated with $2-\left[{ }^{125} \mathrm{I}\right]$-iodomelatonin $(\boldsymbol{\square}=30 \mathrm{pM}, \Delta=100 \mathrm{pM}$, $\alpha=0.037$, Supplemental Fig. $2 \mathrm{C})$ and carbaryl $\left(\mathrm{K}_{\mathrm{B}}=3790 \mathrm{nM}\right.$, $\alpha=0.017$, Fig. $4 \mathrm{~A}$ ) at $\mathrm{hMT}_{1}$, the levels of maximal fractional inhibition of binding decreased with increasing concentrations of radioligand. Because 2-[ $\left.{ }^{125} \mathrm{I}\right]$-iodomelatonin is an agonist radioligand, additional titration tests for luzindole and carbaryl binding to $\mathrm{CHO}-\mathrm{hMT}_{1}$ membranes were conducted in resting buffer to minimize confounding effects associated with $\mathrm{G}$ protein coupling. Luzindole $\left(\mathrm{K}_{\mathrm{B}}=62.6 \mathrm{nM}, \alpha<0.001\right.$, Supplemental Fig. 2E) and carbaryl $\left(\mathrm{K}_{\mathrm{B}}=4400 \mathrm{nM}, \alpha<0.001\right.$, Fig. 4C) completely inhibited higher than $1000 \mathrm{pM} 2-\left[{ }^{125} \mathrm{I}\right]-$ iodomelatonin binding at $\mathrm{hMT}_{1}$ in resting buffer, thus providing supportive evidence of an orthosteric binding mechanism. To corroborate the likely orthosteric binding modes of the other cluster 1 carbamate insecticides, we tested their ability to alter the dissociation rate of $2-\left[{ }^{125} \mathrm{I}\right]$-iodomelatonin from $\mathrm{hMT}_{1}$ and $\mathrm{hMT}_{2}$ bound in resting buffer. Alterations in radioligand dissociation rate by ligands, at concentrations lower than those that would significantly compete for binding with cold orthosteric dissociation initiators, are indicative of an allosteric binding mode. There were no rate differences detected in $2-\left[{ }^{125} \mathrm{I}\right]$-iodomelatonin $(100 \mathrm{pM})$ dissociation from $\mathrm{hMT}_{1}$ and $\mathrm{hMT}_{2}$ initiated by melatonin $(10 \mu \mathrm{M})$ when tested in the absence ( $\mathrm{MT}_{1}$ vehicle: 0.437 minute ${ }^{-1} ; \mathrm{MT}_{2}$ vehicle: 0.0827 minute ${ }^{-1}$ ) or presence of test compounds (100 $\mu \mathrm{M}$ luzindole, carbaryl, fenobucarb, bendiocarb, or bendiocarb; Supplemental Fig. 3; Supplemental Table 2).

Apparent Efficacy of Carbamate Insecticides in

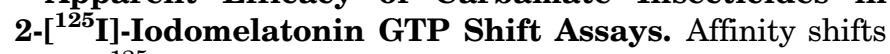
for $2-\left[{ }^{125} \mathrm{I}\right]$-iodomelatonin competition binding $(75 \mathrm{pM})$ by carbamates with or without $\mathrm{G}$ protein inactivation by $100 \mu \mathrm{M}$ GTP, $1 \mathrm{mM}$ EDTA.Na $\mathrm{Na}_{2}$, and $150 \mathrm{mM} \mathrm{NaCl}$, were used to define apparent efficacy (affinity decrease/rightward shift for agonists, no change for antagonists, affinity increase/leftward shift for inverse agonists) (Lefkowitz et al., 1976; Nonno et al., 1998). For reference, in our system, competition binding in resting buffer decreased the affinity of full agonist, melatonin, for both $\mathrm{hMT}_{1}$ and $\mathrm{hMT}_{2}$ receptors $\left(\mathrm{hMT}_{1} \Delta \mathrm{K}_{\mathrm{i} \text { (GTP-control) }}=\right.$ -1.19; $\mathrm{hMT}_{2} \Delta \mathrm{K}_{\mathrm{i}(\mathrm{GTP} \text {-control })}=-0.41$; Supplemental Fig. 4, A and B; Table 3). Resting buffer did not change affinity for carbaryl, fenobucarb, bendiocarb, or carbofuran at $\mathrm{hMT}_{1}$ suggesting antagonist efficacy (Figs. 5A; Supplemental Fig. 4, E and G; Table 3; (Popovska-Gorevski et al., 2017), whereas at $\mathrm{hMT}_{2}$, affinities are decreased displaying differences consistent with an agonist (Figs. 5B; Supplemental Fig. 4, F and H; Table 3; (Popovska-Gorevski et al., 2017)).

In Vitro Competition of Carbamate Insecticides for 2-[ $\left.{ }^{125} I\right]$-Iodomelatonin Binding to Melatonin Receptors in C3H/HeN Mouse Brain Slices. Carbaryl, fenobucarb, and bendiocarb were selected for experiments in brain slices from mice based on their affinity at $\mathrm{hMT}_{1}$ in $\mathrm{CHO}$ cells (Table 1 ). Of note, quantitative receptor autoradiography in mouse brain tissue utilizing $2-\left[{ }^{125} \mathrm{I}\right]$-iodomelatonin cannot detect quantifiable $\mathrm{MT}_{2}$ receptor binding, as indicated by lack of specific radiolabeled sites in brain slices from $\mathrm{MT}_{1}$ global

$\boldsymbol{\nabla}=300 \mathrm{pM}, \diamond=600 \mathrm{pM}, \diamond=1000 \mathrm{pM})$ and control or carbaryl $(10 \mathrm{nM}-1 \mathrm{mM})$ in active (A and $\mathrm{B})$ and resting buffer $(\mathrm{C})(+100 \mu \mathrm{M}$ GTP, 1 mM EDTA.Na 2 $150 \mathrm{mM} \mathrm{NaCl}$ ). Symbols shown are the mean from representative experiments independently repeated three times. See Supplemental Table 1 for derived binding constants $\left(\mathrm{K}_{\mathrm{B}}\right)$ and cooperativity factors $(\alpha ; \alpha<0.01$, orthosteric; $\alpha \geq$ 0.01 , allosteric). 

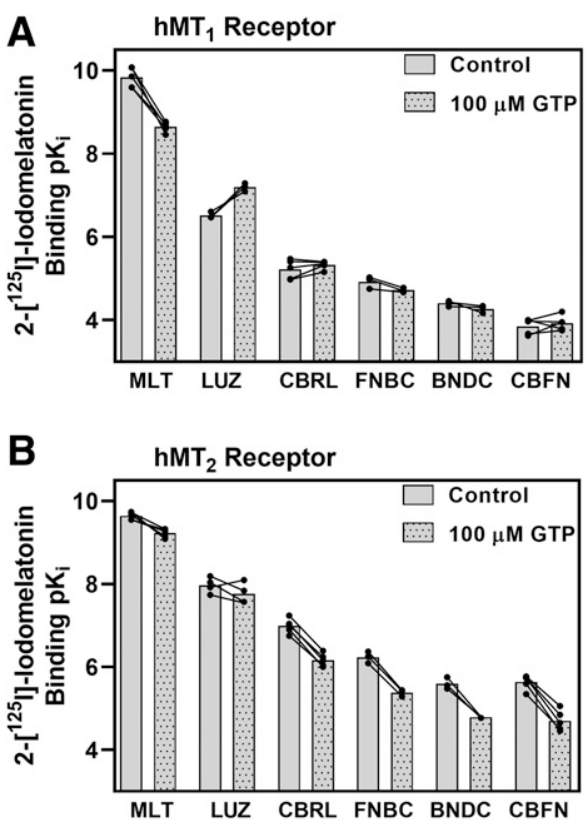

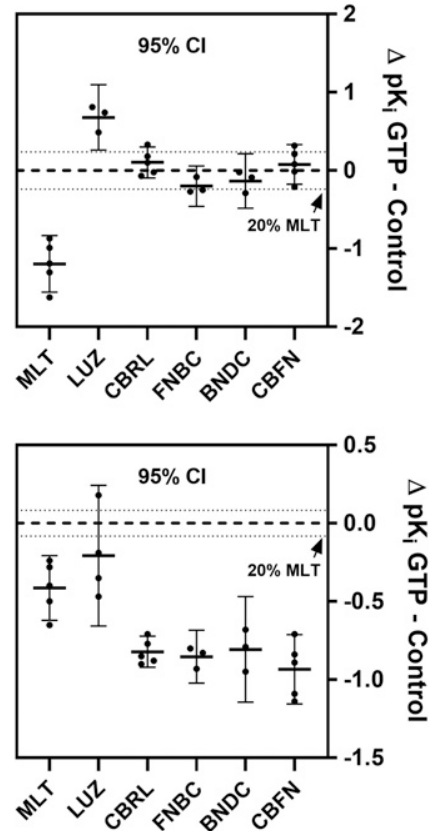

Fig. 5. Carbamate insecticides compete for $2-\left[{ }^{125} \mathrm{I}\right]-$ iodomelatonin binding to $\mathrm{hMT}_{1}$ and $\mathrm{hMT}_{2}$ melatonin receptors without and with $\mathrm{G}$ protein inactivation. Membranes from CHO cells stably expressing $\mathrm{hMT}_{1}$ (A) or $\mathrm{hMT}_{2}$ (B) melatonin receptors were incubated with $2-\left[{ }^{125} \mathrm{I}\right]-$ iodomelatonin $(75 \mathrm{pM})$ in the absence and the presence of various concentrations of melatonin (MLT), luzindole (LUZ), carbaryl ${ }^{\dagger}$ (CBRL), fenobucarb (FNBC), bendiocarb (BNDC), or carbofuran ${ }^{\dagger}$ (CBFN). ${ }^{\dagger}$ Denotes Ki values transformed from data obtained from Popovska-Gorevski et al. (2017). See Supplemental Fig. 4 for binding curves and Table 3 for derived affinity constants. (Left panels) The ordinate represents binding affinity in the absence (solid bars) and presence (dotted bars) of GTP expressed as $\mathrm{pK}_{\mathrm{i}}$. Connected points indicate values from simultaneously run experiments with the same tissue. (Right panels) The ordinate represents the mean differences in $\mathrm{pK}_{\mathrm{i}}\left(\mathrm{pK}_{\mathrm{iGTP}}-\mathrm{pK}_{\mathrm{iControl}}\right.$ $\left.=\Delta \mathrm{pK}_{\mathrm{i}}\right)$ and $95 \%$ confidence intervals $(95 \% \mathrm{CI})$ produced by $\mathrm{G}$ protein inactivation. Ligands are classified as agonists (mean $\Delta \mathrm{pK}_{\mathrm{i}}$ below $20 \%$ MLT dashed line), antagonists (mean $\Delta \mathrm{pK}_{\mathrm{i}}$ between $20 \%$ and $-20 \%$ MLT dashed lines), or inverse agonists (mean above $-20 \%$ MLT dashed line). knock out mice (Liu et al., 1997; Dubocovich et al., 1998). However, $\mathrm{MT}_{2}$ melatonin receptor mRNA has been detected by in situ hybridization (Dubocovich et al., 1998; Hunt et al., 2001) and protein has been identified via immunohistochemistry in rodents (Lacoste et al., 2015). Furthermore, attempts to label melatonin receptors with an $\mathrm{MT}_{2}$ specific radioligand (Legros et al., 2016) failed to display specific binding in the SCN, PVNT, or PT, further supporting that $\mathrm{MT}_{2}$ levels in rodent brain are too low to detect via available melatonin receptor radioligands by quantitative receptor autoradiography. Representative autoradiograms of adjacent $(20 \mu \mathrm{m})$ brain sections from a single WT mouse treated with vehicle, melatonin (1 $\mu \mathrm{M})$, or carbaryl $(1-100 \mu \mathrm{M})$ display a concentrationdependent decrease in visible $2-\left[{ }^{125} \mathrm{I}\right]$-iodomelatonin labeling in the SCN, PVT, and PT (Fig. 6). These images also reveal the expected competition by positive control melatonin $(1 \mu \mathrm{M}$; nonspecific binding; (Liu et al., 1997; Masana et al., 2000) for $2-\left[{ }^{125} \mathrm{I}\right]$-iodomelatonin binding sites in the SCN, PVT, and PT (Fig 6, A and B). Quantification of optical density in autoradiograms revealed that carbaryl competed in a concentration-dependent manner for $2-\left[{ }^{125} \mathrm{I}\right]$-iodomelatonin $(75 \mathrm{pM})$ binding in the $\operatorname{SCN}\left(\mathrm{F}_{3,21}=42.07, P<0.001\right)$, the PVT
A

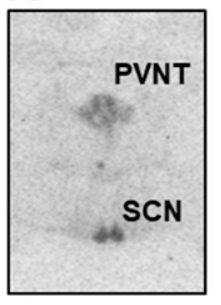

\section{Vehicle}

B

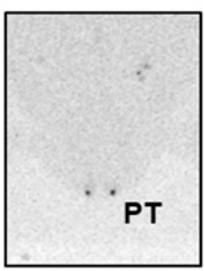

Vehicle

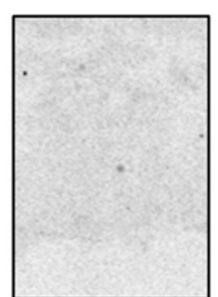

$1 \mu \mathrm{M}$
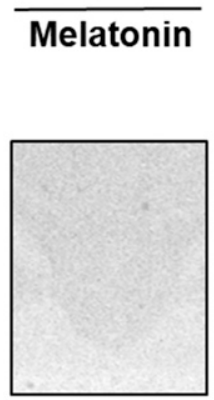

$1 \mu \mathrm{M}$

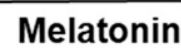

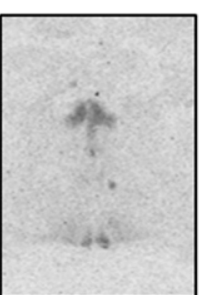

$1 \mu \mathrm{M}$

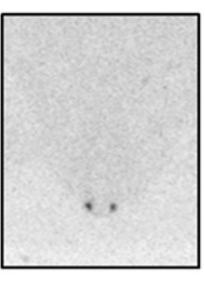

$1 \mu \mathrm{M}$

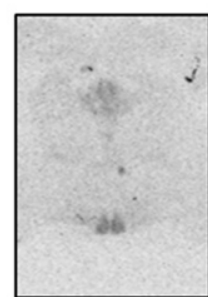

$10 \mu \mathrm{M}$

Carbaryl

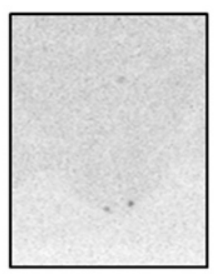

$10 \mu \mathrm{M}$

Carbary

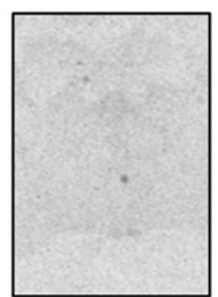

$100 \mu \mathrm{M}$

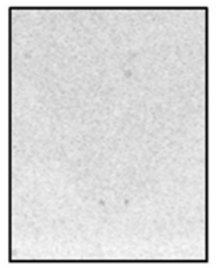

$100 \mu \mathrm{M}$
Fig. 6. Representative autoradiograms show carbaryl competes in vitro for $2-\left[{ }^{125} \mathrm{~T}\right]$-iodomelatonin binding at melatonin receptors in slices containing the SCN, PVT, and PT from C3H/HeN WT mice. (A and B) Vehicle, melatonin ( $1 \mu \mathrm{M})$, or carbaryl $(1,10,100 \mu \mathrm{M})$ treatments in representative magnified images taken from autoradiograms containing adjacent coronal sections containing the SCN and PVT (A) or PT (B) treated with 2 - $\left[{ }^{125} \mathrm{I}\right]$-iodomelatonin $(75 \mathrm{pM})$. Additional treatments are listed below in each section. 
$\left(\mathrm{F}_{3,21}=25.83, P<0.0001\right)$, and the $\mathrm{PT}\left(\mathrm{F}_{3,12}=34.63, P<0.0001\right)$ compared with vehicle-treated adjacent sections (Fig. 7, A-C; Supplemental Table 3). Similar competition was exhibited by carbaryl in brain slices from $\mathrm{MT}_{2} \mathrm{KO}$ mice in the $\mathrm{SCN}\left(\mathrm{F}_{3,19}=\right.$ $22.60, P<0.001)$, the PVT $\left(\mathrm{F}_{3,16}=22.19, P<0.001\right)$, and the PT $\left(\mathrm{F}_{3,12}=34.16, P<0.001\right.$; Fig 7 , D-F; Supplemental
Table 3). Fenobucarb and bendiocarb (1-100 $\mu \mathrm{M})$ also competed in a concentration-dependent manner for $2-\left[{ }^{125} \mathrm{I}\right]$ iodomelatonin $(75 \mathrm{pM})$ binding in the $\operatorname{SCN}\left(\mathrm{F}_{3,7}=17.80\right.$, $\left.P<0.001 ; \mathrm{F}_{3,7}=21.37, P<0.001\right)$, in the $\mathrm{PVT}\left(\mathrm{F}_{3,8}=24.95\right.$, $\left.P<0.001 ; \mathrm{F}_{3,7}=33.14, P<0.001\right)$, and in the $\mathrm{PT}\left(\mathrm{F}_{4,5}=19.27\right.$, $\left.P<0.01 ; \mathrm{F}_{4,5}=21.04, P<0.01\right)$ compared with vehicle-treated
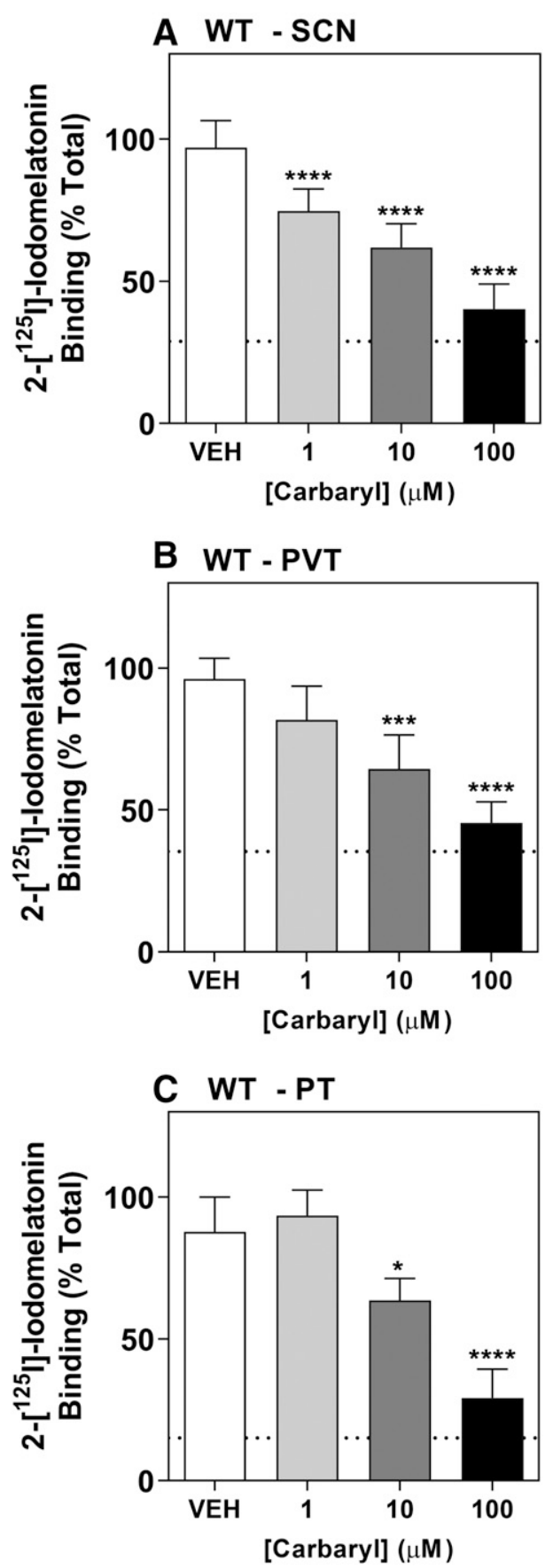
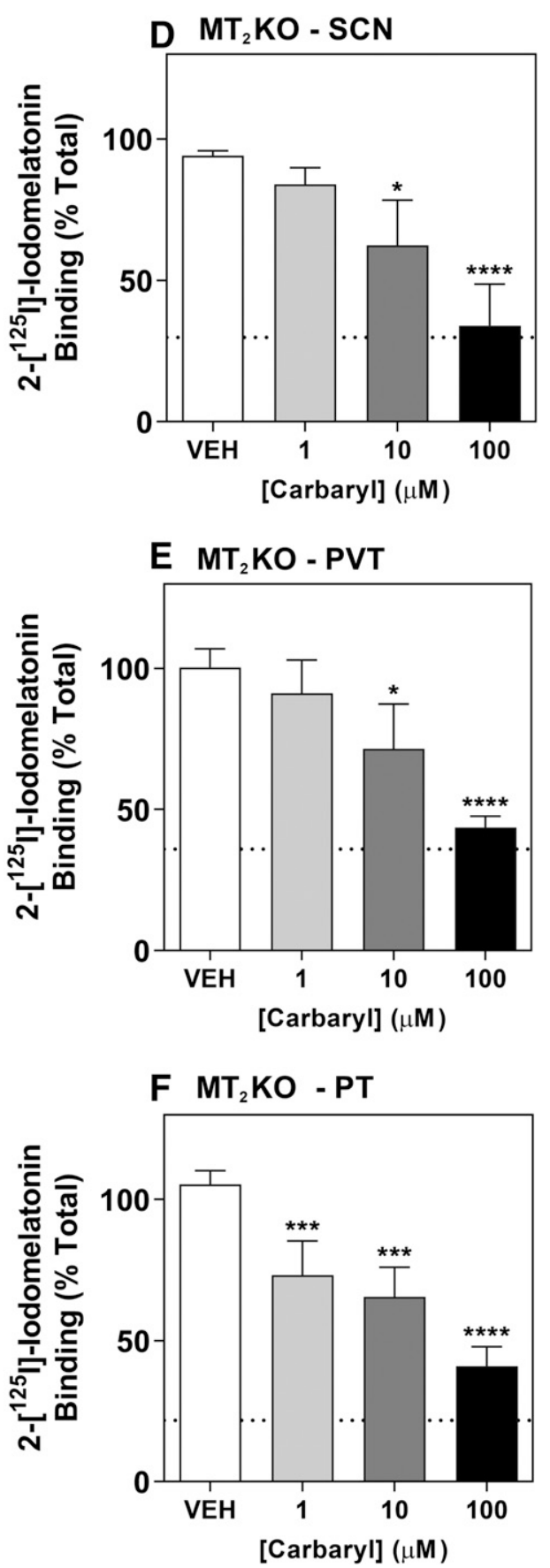

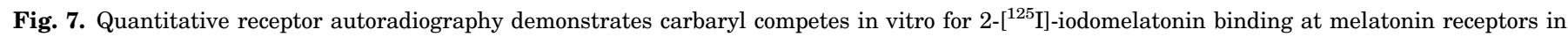

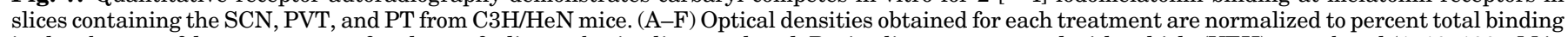

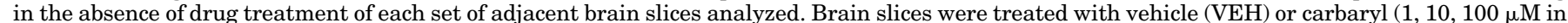

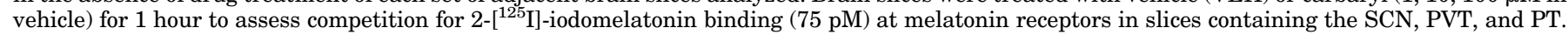

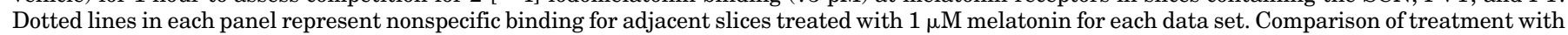

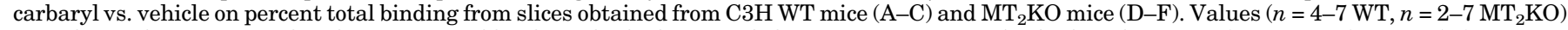

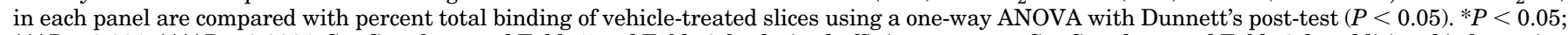

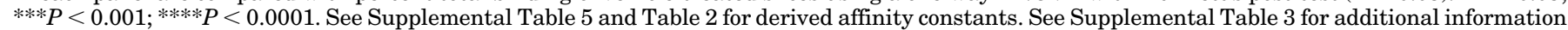
regarding descriptive statistics and data comparisons. 
TABLE 2

Affinity constants of carbamate insecticides compete for $2-\left[{ }^{125} \mathrm{I}\right]$-iodomelatonin binding to SCN, PVT, and PT in brain slices from $\mathrm{C} 3 \mathrm{H} / \mathrm{HeN}$ mice

Carbaryl, fenobucarb, and bendiocarb $(1-100 \mu \mathrm{M})$ competed for 2-[ $\left.{ }^{125} \mathrm{I}\right]$-iodomelatonin $(75 \mathrm{pM})$ binding to melatonin receptors in SCN, PVT, and $\mathrm{PT} \mathrm{C} 3 \mathrm{H} / \mathrm{HeN}$ mouse brain slices as determined by quantitative receptor autoradiography. $\mathrm{K}_{\mathrm{i}}$ values determined by the method of Cheng and Prusoff (1973) were used to calculate $\mathrm{pK}_{\mathrm{i}}$ values. Shown are mean $\mathrm{pK}_{\mathrm{i}}$ values and $95 \%$ confidence intervals from independent determinations: SCN $(n=3-7)$, PVT $(n=3-7)$, and PT $(n=2-4)$. $\mathrm{pK}_{\mathrm{i}}$ for $\mathrm{hMT}_{1}$ expressed in CHO cells is shown for comparison (Fig. 3; Table 1).

\begin{tabular}{|c|c|c|c|c|}
\hline \multirow[b]{2}{*}{ Ligand } & \multicolumn{4}{|c|}{ Competition for $2-\left[{ }^{125} \mathrm{I}\right]$-iodomelatonin binding in vitro } \\
\hline & $\begin{array}{c}\mathrm{hMT}_{1} \mathrm{CHO} \\
\mathrm{pK}_{\mathrm{i}}\end{array}$ & $\begin{array}{c}\text { Mouse SCN } \\
\mathrm{pK}_{\mathrm{i}}\end{array}$ & $\begin{array}{c}\text { Mouse PVT } \\
\mathrm{pK}_{\mathrm{i}}\end{array}$ & $\begin{array}{c}\text { Mouse PT } \\
\mathrm{pK}_{\mathrm{i}}\end{array}$ \\
\hline Carbaryl & $5.52(5.29-5.75)$ & $5.50(5.30-5.71)$ & $5.51(5.03-5.98)$ & $5.10(4.76-5.44)$ \\
\hline Fenobucarb & $5.01(4.89-5.13)$ & $4.93(4.27-5.58)$ & $5.18(4.59-5.78)$ & $6.17(2.36-9.97)$ \\
\hline Bendiocarb & $4.38(4.30-4.45)$ & $4.74(3.70-5.77)$ & $4.41(4.07-4.76)$ & $3.70(3.39-4.00)$ \\
\hline
\end{tabular}

adjacent sections (Supplemental Fig. 5; Supplemental Table 4). Affinity $\left(\mathrm{pK}_{\mathrm{i}}\right.$ ) values for carbaryl, fenobucarb, and bendiocarb regarding competition for 2- $\left[{ }^{125} \mathrm{I}\right]$-iodomelatonin binding in these brain regions are shown in Supplemental Table 5 and Table 2. Across all treatments and experiments, mean nonspecific binding determined by $1 \mu \mathrm{M}$ melatonin was $31.65 \% \pm 8.22 \%, 36.87 \% \pm$ $8.82 \%$, and $17.35 \% \pm 5.82 \%$ in the SCN, PVT, and PT, respectively.

Ex Vivo Time-Course for Competition of Carbaryl for 2-[ $\left.{ }^{125} I\right]-$ Iodomelatonin Binding in Brain Slices Containing the SCN. Carbaryl was chosen for in vivo administration experiments due to its superior affinity at $\mathrm{hMT}_{1}$ recombinant receptors (Fig. 3; Table 1) and potency at native mouse $\mathrm{MT}_{1}$ (Figs. 6 and 7; Table 2) compared with other carbamates tested. Of note, ex vivo binding using $2\left[{ }^{125} \mathrm{I}\right]$-iodomelatonin cannot detect quantifiable levels of specific binding to $\mathrm{MT}_{2}$, allowing quantification of only $\mathrm{MT}_{1}$ receptor affinity as previously mentioned. In vivo administration of carbaryl $(10 \mathrm{mg} / \mathrm{kg}$, i.p.) reduced specific $2-\left[{ }^{125} \mathrm{I}\right]$-iodomelatonin binding $(50 \mathrm{pM})$ in SCN brain slices processed ex vivo at 30,60 , and 120 minutes postadministration compared with vehicle-treated mice $\left(\mathrm{F}_{4,23}=\right.$ 13.21, $P<0.001$ ), which recovered by 240 minutes (Fig. 8A; Supplemental Table 3). Carbaryl also reduced specific $2-\left[{ }^{125} \mathrm{I}\right]-$ iodomelatonin binding $(50 \mathrm{pM})$ in PVT brain slices processed ex vivo $\left(\mathrm{F}_{4,23}=5.79, P<0.01\right.$; Fig. $8 \mathrm{~B}$; Supplemental Table 3$)$. Interestingly, specific binding in the PVT was found to be specifically increased at 240 minutes versus control sections (Fig. 8B; Supplemental Table 3). In the PT, specific 2- $\left[{ }^{125} \mathrm{I}\right]-$ iodomelatonin binding was reduced by carbaryl only at 60 minutes postadministration $(P<0.05$; Fig. $8 \mathrm{C})$.

In Vivo Administration of Carbaryl at CT 10 PhaseAdvances Onset of Circadian Running Wheel Activity Rhythms. Figure 9, A-C, shows representative actograms for single mice treated with vehicle (15\% ethanol/saline), melatonin $(3 \mathrm{mg} / \mathrm{kg}$, s.c.), or carbaryl $(10 \mathrm{mg} / \mathrm{kg}$, i.p.) for three consecutive days at CT 10,2 hours before onset of activity (CT 12). Quantification of phase shifts indicates that positive control melatonin and experimental drug carbaryl produced significant phase-advances of onset of activity rhythms compared with vehicle-treated controls $\left(\mathrm{F}_{2,20}=29.59 ; P<0.05\right.$; Dunnett's post-test; Fig. 9D; Supplemental Table 3). A single mouse was excluded from the carbaryl treatment group because it met exclusion criterion of two thirds of the injections falling outside of the acceptable range (CT 9-11).

\section{Discussion}

Carbamate insecticides sharing high structural similarity to melatonin bind competitively to the orthosteric site of the human recombinant $\mathrm{MT}_{1}$ and $\mathrm{MT}_{2}$ melatonin receptors. Pharmacological data validated in silico and pharmacoinformatic predictions for carbamates, demonstrating binding to the orthosteric sites of melatonin receptors with antagonist apparent efficacy for $\mathrm{hMT}_{1}$ and agonist apparent efficacy for $\mathrm{hMT}_{2}$ receptors. Furthermore, carbaryl competed for $2-\left[{ }^{125} \mathrm{I}\right]-$ iodomelatonin binding in mouse brain areas with high expression of melatonin receptors involved in the modulation of circadian (i.e., SCN), neurochemical, behavioral (i.e., PVT), and endocrine (i.e., PT) functions. Lastly, carbaryl phaseadvanced overt circadian activity rhythm onsets akin to melatonin when given to $\mathrm{C} 3 \mathrm{H} / \mathrm{HeN}$ wild-type mice 2 hours before (CT 10) onset of activity (CT 12) at subjective dusk. Here we discuss implications for these novel properties of carbamate insecticides in toxicological outcomes not explained by canonical actions at AChE as well as potential limitations of the present data.

The Chem2Risk knowledge base pipeline was used to discover environmental melatonin receptor ligands. Cluster 1 carbamate insecticides (carbaryl, carbofuran, fenobucarb, bendiocarb, and fenoxycarb), with Tanimoto indices $\mathrm{S}_{2 \mathrm{D}}$ and $\mathrm{S}_{3 \mathrm{D}}>0.4$ possess typical melatonin pharmacophore fingerprints, which include an aromatic ring system and a carbonyl moiety in position to leverage interactions with the binding site residues H195 or Q181 in $\mathrm{MT}_{1}$ and N175, Q194 or H208 in $\mathrm{MT}_{2}$. Comparative molecular docking of top carbamates with the recently reported crystal structures (Johansson et al., 2019; Stauch et al., 2019) revealed a considerable overlap of binding pocket residues. Carbamate insecticides competitively bind to the $\mathrm{MT}_{1}$ and $\mathrm{MT}_{2}$ melatonin receptor orthosteric sites likely formed by the aforementioned residues (Lazareno and Birdsall, 1995; Kenakin, 2009). The higher selectivity of carbaryl for binding to the $\mathrm{hMT}_{2}$ receptors over the $\mathrm{hMT}_{1}$ (33-fold) (Popovska-Gorevski et al., 2017) is likely attributable to the ring stacking interactions with H208 and partial occupancy of the hydrophobic cavity formed by the residues V124, I125, P212, I213, and F260 similar to reported ligand binding modes of selective $\mathrm{MT}_{2}$ ligands (Rivara et al., 2005; Pala et al., 2013a,b; Jockers et al., 2016; Johansson et al., 2019). Carbamates, carbaryl, bendiocarb, and fenobucarb competed for $\mathrm{mMT}_{1}$ receptors expressed in the SCN, PVT, and $\mathrm{PT}$ in $\mathrm{C} 3 \mathrm{H} / \mathrm{HeN}$ mouse brain slices yielding $\mathrm{pK}_{\mathrm{i}}$ values similar to the affinity constants for binding at recombinant $\mathrm{hMT}_{1}$ receptors expressed in $\mathrm{CHO}$ cells. Altogether, our computational predictions were translatable interactions for recombinant human and endogenous mouse melatonin receptors and suggest these model systems may be useful in risk assessment of environmental compounds to human health 


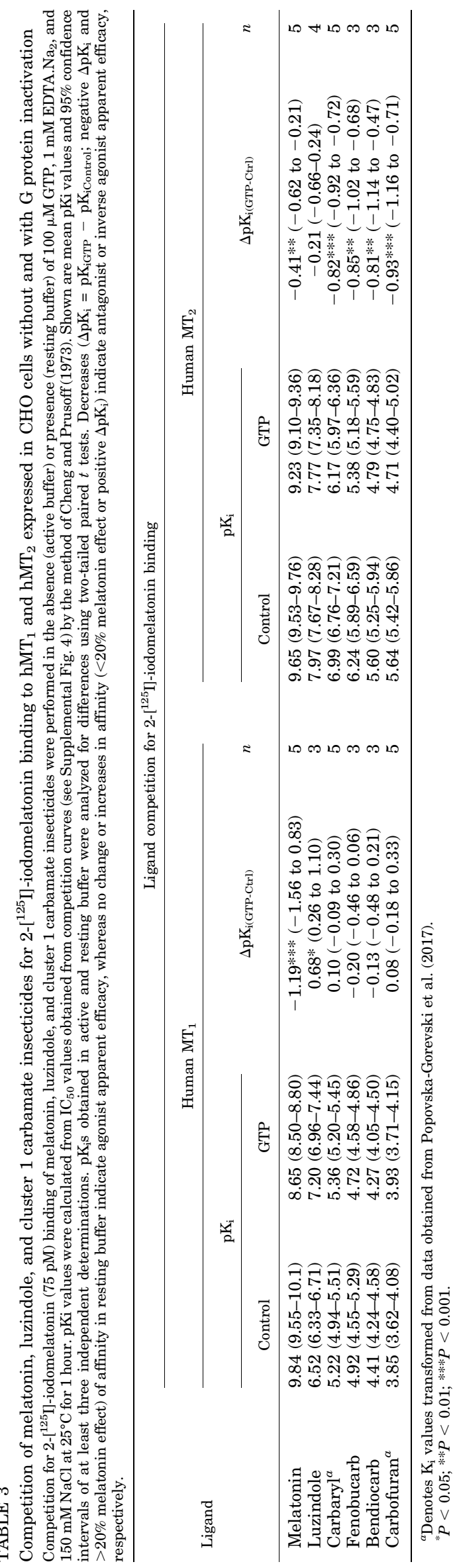

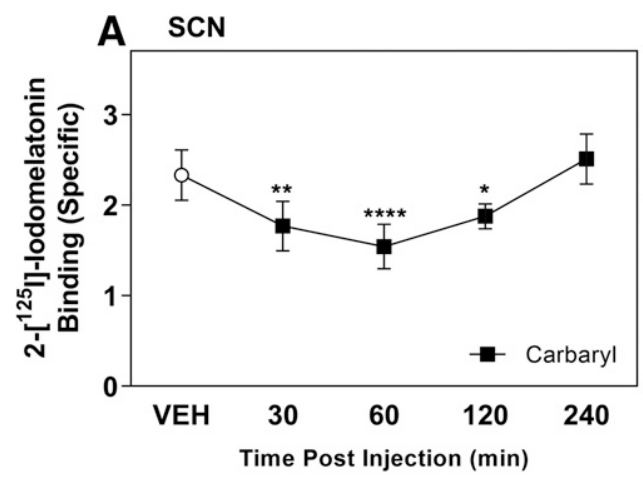
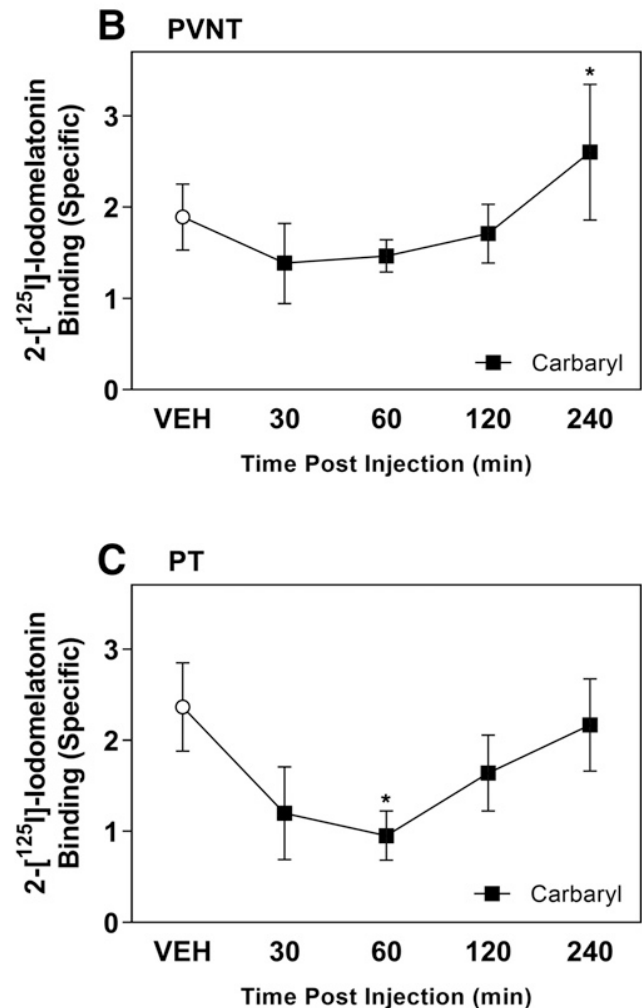

Fig. 8. Carbaryl competes ex vivo for $2-\left[{ }^{125} \mathrm{I}\right]$-iodomelatonin binding at melatonin receptors in slices containing the SCN, PVT, and PT from C3H/HeN WT mice. Specific binding of 2-[ $\left.{ }^{125} \mathrm{I}\right]$-iodomelatonin (50 pM) ex vivo in the SCN (A), PVT (B), or PT (C) of brain slices quantified at $0,30,60,120$, and 240 minutes after in vivo administration of vehicle (VEH) or carbaryl $(10 \mathrm{mg} / \mathrm{kg}$ i.p. in vehicle). Values $(n=3-6)$ are compared with VEH $(n=10)$ using a one-way ANOVA with Dunnett's post-test $(P<0.05)$. Specific binding was determined by subtracting nonspecific values from adjacent slices treated with only the radioligand. ${ }^{*} P<0.05 ; * * P<0.01$; $* * * * P<0.0001$.

based on success here with predictions relevant to the melatonin system.

Ex vivo quantitative receptor autoradiography data from the current report are in line with previously reported findings for the temporal pharmacokinetic (Declume and Benard, 1977; Krolski et al., 2003), biochemical (Moser et al., 2012, 2015a,b; Wang et al., 2014), and behavioral effects of carbaryl (Albright and Simmel, 1979; Ruppert et al., 1983; Moser et al., 1988; Moser, 1995). Peak effects on behavior, brain cholinesterase inhibition, and radiolabeled drug recovery in brain tissue occur from 30 to 120 minutes after delivery of carbaryl depending on the route of administration. Therefore, our results from time course experiments showing ex vivo competition binding of 

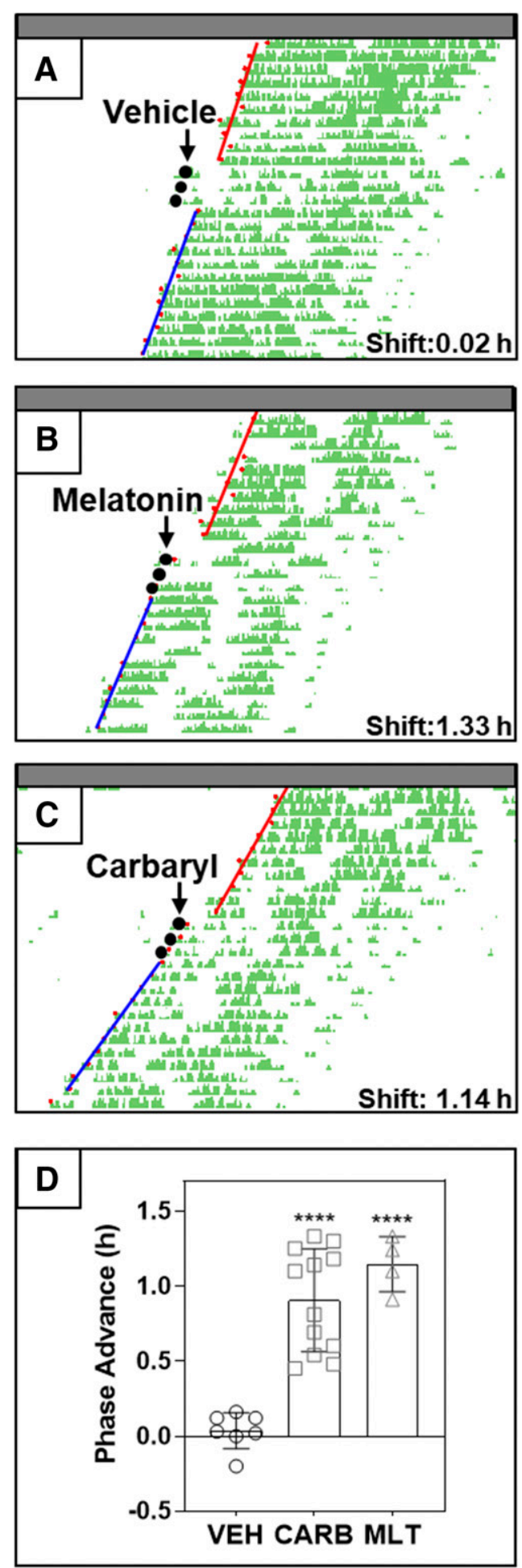

Fig. 9. Carbaryl phase-advances running wheel activity onset after 3 days of injections at CT 10, similar to melatonin. Representative running wheel activity actograms from $\mathrm{C} 3 \mathrm{H} / \mathrm{HeN}$ mice treated with vehicle (VEH; saline $15 \%$ EtOH i.p.; $n=7$ ) (A), carbaryl (10 mg/kg i.p.; $n=12)(B)$, or melatonin $(3 \mathrm{mg} / \mathrm{kg}$, s.c.; $n=4)(\mathrm{C})$ for three consecutive days, indicated by the black dots. (D) Quantification of phase shift by vehicle, carbaryl, or melatonin treated mice. Phase shift values were compared to vehicle by one-way ANOVA followed by Dunnett's post-test $* * * P<0.001$.

carbaryl at mouse melatonin receptors maximally at 60 minutes postadministration in brain areas expressing $\mathrm{mMT}_{1}$ melatonin receptors $(\mathrm{SCN}, \mathrm{PT})$ are in agreement with reported temporal presentation of effects on behavior and biodistribution to the brain related to interactions with cholinergic systems. This study was admittedly limited in that we did not explore exact brain concentrations of carbaryl when administered at $10 \mathrm{mg} / \mathrm{kg}$ i.p.; however, this dose of carbaryl competed ex vivo for binding to melatonin receptors in the SCN and maximally phase-advanced circadian phase compared to melatonin in a translational behavioral mouse model.

The present data demonstrate interactions of carbaryl and/or metabolites, and/or melatonin itself as carbaryl can increase its production (Attia et al., 1991a,b) at brain melatonin receptors with resulting behavioral effects on circadian phase. Maximal functional response for phase shift at CT 10 are obtained with 1 and $3 \mathrm{mg} / \mathrm{kg}$ melatonin acting on brain $\mathrm{MT}_{1}$ melatonin receptors in the SCN (Benloucif and Dubocovich, 1996; Dubocovich et al., 1998; Stein et al., 2020). Acute carbaryl administration at subjective dusk (CT 10) maximally phase-shifted circadian activity rhythms similarly to melatonin receptor agonists (Dubocovich et al., 2005; Liu et al., 2016) in contrast to present results from GTP-shift assays, suggesting antagonist apparent efficacy. Behavioral efficacy of compounds acting at melatonin receptors has been shown to vary with time of administration as well as chronobiological context (Stein et al., 2020), suggesting the need to test carbaryl at other times in the circadian cycle sensitive to melatonin receptor stimulation (i.e., CT 1-3) (Benloucif and Dubocovich, 1996) or in the jet-lag paradigm (Dubocovich et al., 2005). Drug-mediated phase shifts directly translate from the $\mathrm{C} 3 \mathrm{H} / \mathrm{HeN}$ mouse to human models (Benloucif and Dubocovich, 1996; Burgess et al., 2008). Therefore, carbaryl could be a possible circadian modulator in humans via actions at SCN melatonin receptors. However, it is possible that carbaryl exposure may also influence circadian physiology through reported modulation of pineal and blood melatonin levels, levels of pineal serotonin as well as its precursors, and hypothalamic uptake of norepinephrine (Jablońska and Brzeziński, 1990; Attia et al., 1991a,b). Therefore, carbaryl may dually regulate the synthesis of melatonin and also directly compete for binding at melatonin receptors to influence mediated processes. Context for melatonin receptor signaling and physiological relevance are also important considerations, as time of day (Benloucif and Dubocovich, 1996; Gillette and Mitchell, 2002) and protein composition of the system under study (Liu et al., 2019) can significantly affect interpretation of results. Lastly, we must also acknowledge the ability of the cholinergic system to influence phase of circadian rhythms on its own (Liu and Gillette, 1996). However, the peak of sensitivity for cholinergic regulation of circadian rhythms (CT 17-19) is outside the sensitive periods (CT 1-3 and 9-11) for modulation of circadian rhythms by melatonin receptor agonists (Benloucif and Dubocovich, 1996; Dubocovich et al., 2005).

Several other off-target receptors and proteins could contribute to the phase resetting effect of carbaryl. The PubChem BioAssay data base (https://pubchem.ncbi.nlm.nih.gov), with over 1700 entries from biologic screening platforms such as ChEMBL (https://www.ebi.ac.uk/chembl/), Tox21 (https:// ntp.niehs.nih.gov/whatwestudy/tox21/toolbox/index.html), and the National Center for Advancing Translational Science (https://ncats.nih.gov/etb), lists potential carbaryl targets at concentrations below $10 \mu \mathrm{M}$ to include the pregnane $\mathrm{X}$ receptor (potency $=3.2 \mu \mathrm{M}$; Tox21) and the aryl hydrocarbon receptor (potency = 5.3 $\mu \mathrm{M}$; Tox21). Environmental dioxins alter circadian rhythms via aryl hydrocarbon receptor-mediated interference 
of clock gene transcription and reduce phase resetting induced by light pulses in mice (Xu et al., 2010, 2013; Tischkau et al., 2011). Dioxins affect clock genes and behavioral rhythms, contributing to altered glucose metabolism, insulin resistance, and sleep disorders. However, the time of circadian sensitivity for these effects has not been reported, making comparisons with the range of sensitivity for melatonin receptor-mediated phase shifts of circadian activity difficult. Action of carbaryl at other proteins was also investigated using the National Institute of Mental Health Psychoactive Drug Screening Program screening for inhibition of radioligand binding at 40 GPCR targets, which only revealed affinity for serotonin receptor $2 \mathrm{~B}\left(5 \mathrm{HT}_{2 \mathrm{~B}}\right)$ (Besnard et al., 2012). Carbaryl affinity for $5 \mathrm{HT}_{2 \mathrm{~B}}\left(\mathrm{~K}_{\mathrm{i}}=5.2 \mu \mathrm{M}\right)$ suggests that we cannot rule out actions at this receptor; however, serotonin maximally modulates circadian phase at ZT 6 (Prosser et al., 1993; Gillette and Mitchell, 2002) outside of the widows of sensitivity to melatonin receptor ligands and there is no evidence that $5 \mathrm{HT}_{2 \mathrm{~B}}$ activity modulates circadian biology.

Routes of exposure for carbaryl in the general population range from inhalation and dermal exposure predominately at occupational sites to oral exposure from contaminated food and water supplies on the environmental side (Hazardous Substasnces Data Bank, National Library of Medicine, Gunasekara et al., 2008). The level of daily exposure to carbamate insecticides in humans not occupationally exposed is reportedly $0.02-0.12 \mu \mathrm{g} / \mathrm{kg}$ body weight/day or $1.4-8.4 \mu \mathrm{g} / \mathrm{day}$ from dietary sources (Duggan et al., 1983; Gartrell et al., 1985, 1986; Hazardous Substasnces Data Bank, National Library of Medicine). Carbaryl does not accumulate in the body, as it is rapidly metabolized to 1-naphthol, which is used as a biomarker of exposure (Shealy et al., 1997; Gunasekara et al., 2008). Doses of carbaryl required to produce cholinergic effects are generally higher than the dose used in the present study (10 $\mathrm{mg} / \mathrm{kg}$, i.p.) to compete for binding at brain melatonin receptors ex vivo as well as to phase-shift circadian activity rhythms in $\mathrm{C} 3 \mathrm{H} / \mathrm{HeN}$ mice. Doses of carbaryl that produce clinically significant cholinesterase inhibition in brain and blood are equal to or above $15 \mathrm{mg} / \mathrm{kg}$ i.p. or oral gavage (Ruppert et al., 1983), with one study finding no effects of carbaryl on brain cholinesterase activity with doses up to $42.5 \mathrm{mg} / \mathrm{kg}$ via oral gavage (Wang et al., 2014). Conversely, another study by Moser et al. (2015a) found that doses of 3 and $7.5 \mathrm{mg} / \mathrm{kg}$ carbaryl via oral gavage significantly reduced brain and blood cholinesterase activity by $10 \%-30 \%$ and $30 \%-50 \%$, respectively, compared with controls. However, many of the behavioral and physiologic effects of carbaryl attributable to effects on the cholinergic system (altered gait, reduced motor responses, convulsions, ptosis, lacrimation, salivation, chewing, decreased body temperature, etc.) are not exhibited in rodent studies until doses of at least $20-30 \mathrm{mg} / \mathrm{kg}$ given intraperitoneally or via oral gavage, with effects only on decreased pupil response and increased ptosis seen below this range at $10 \mathrm{mg} / \mathrm{kg}$ i.p (Moser et al., 1988). Thus, it seems possible that the toxicological implications of carbaryl could be more relevant to the melatonin versus the cholinergic system based on doses required for physiological and clinically relevant effects. Future studies will determine dose relevance below $10 \mathrm{mg} / \mathrm{kg}$ i.p. to address external validity issues with matching environmentally relevant exposure doses for effects of carbaryl on phase shift of circadian rhythms and other chronobiological behaviors.
Our data highlight novel pharmacological properties of carbamate insecticides at melatonin receptors. Carbamates like carbaryl display unique pharmacological properties at melatonin receptors, suggesting their potential to alter physiologically relevant responses independent of or in addition to canonical actions at AChE activity. Based on our data we suggest that pharmacological actions of carbamate insecticides at melatonin receptors should be investigated for potential to produce 1) mistimed melatonin receptor activation, 2) alterations of melatonin rhythms by activating and/or blocking timing cues at nonoptimal times of day or by mistimed phase shifts leading to circadian rhythm desynchronization, 3) disrupted timing of physiologic processes under control of melatonin-mediated time-of-day signaling (i.e., modulation of pancreas metabolic rhythmicity), and/or 4) modulation of core clock gene transcription or rhythmicity. These changes could predispose or contribute to relevant disease pathologies observed after exposure to carbamate insecticides linked indirectly to circadian disruption, particularly those not explained by actions at AChE, such as sleep apnea (Zirlik et al., 2013; Baumert et al., 2018).

\section{Acknowledgments}

We would like to thank Shannon Clough for expert suggestions and technical advice in experiments involving mice and Gregory Wilding from the University at Buffalo Clinical and Translational Science Institute Biostatistics, Epidemiology, and Research Design (BERD) Core for advice on statistical analyses of in vivo experimental data. The receptor binding profile of carbaryl was generously provided by National Institute of Mental Health's Psychoactive Drug Screening Program (NIMH PDSP), Contract HHSN-271-2018-00023-C. NIMH PDSP is directed by Bryan L. Roth at the University of North Carolina at Chapel Hill and Project Officer Jamie Driscoll at NIMH, Bethesda, MD.

\section{Authorship Contributions}

Participated in research design: Jones, Glatfelter, Rajnarayanan, Dubocovich.

Conducted experiments: Jones, Glatfelter, Rajnarayanan.

Performed data analysis: Jones, Glatfelter, Rajnarayanan.

Wrote or contributed to the writing of the manuscript: Jones, Glatfelter, Rajnarayanan, Dubocovich.

\section{References}

Albright ME and Simmel EC (1979) Behavioral effects of the cholinesterase inhibitor and insecticide carbaryl (Sevin). J Biol Psychol 21:25-31.

Ali SA, Khan SA, Naaz I, and Ali AS (2015) Adverse health effects of pesticide exposure in workers of a pesticide manufacturing factory. Biosci Biotechnol Res Commun 8:208-212.

Attia AM, Reiter RJ, Nonaka KO, Mostafa MH, Soliman SA, and el-Sebae AH (1991a) Carbaryl-induced changes in indoleamine synthesis in the pineal gland and its effects on nighttime serum melatonin concentrations. Toxicology 65:305-314.

Attia AM, Reiter RJ, Withyachumnarnkul B, Mostafa MH, Soliman SA, and el-sebae AK (1991b) Chronic administration of sublethal doses of carbaryl increases pineal $\mathrm{N}$-acetyltransferase and hydroxyindole-O-methyltransferase activities and serum melatonin levels. J Pineal Res 10:49-54.

Baron KG and Reid KJ (2014) Circadian misalignment and health. Int Rev Psychiatry 26:139-154.

Baumert BO, Carnes MU, Hoppin JA, Jackson CL, Sandler DP, Freeman LB, Henneberger PK, Umbach DM, Shrestha S, Long S, et al. (2018) Sleep apnea and pesticide exposure in a study of US farmers. Sleep Health 4:20-26.

Benloucif S and Dubocovich ML (1996) Melatonin and light induce phase shifts of circadian activity rhythms in the C3H/HeN mouse. J Biol Rhythms 11:113-125.

Benloucif S, Masana MI, and Dubocovich ML (1997) Responsiveness to melatonin and its receptor expression in the aging circadian clock of mice. Am J Physiol 273: R1855-R1860.

Benloucif S, Masana MI, Yun K, and Dubocovich ML (1999) Interactions between light and melatonin on the circadian clock of mice. J Biol Rhythms 14:281-289.

Beresford IJM, Browning C, Starkey SJ, Brown J, Foord SM, Coughlan J, North PC Dubocovich ML, and Hagan RM (1998) GR196429: a nonindolic agonist at highaffinity melatonin receptors. J Pharmacol Exp Ther 285:1239-1245. 
Besnard J, Ruda GF, Setola V, Abecassis K, Rodriguiz RM, Huang XP, Norval S, Sassano MF, Shin AI, Webster LA, et al. (2012) Automated design of ligands to polypharmacological profiles. Nature 492:215-220.

Bini Dhouib I, Annabi A, Jallouli M, Marzouki S, Gharbi N, Elfazaa S, and Lasram MM (2016) Carbamates pesticides induced immunotoxicity and carcinogenicity in human: a review. J Appl Biomed 14:85-90

Bothorel B, Barassin S, Saboureau M, Perreau S, Vivien-Roels B, Malan A, and Pévet $\mathrm{P}$ (2002) In the rat, exogenous melatonin increases the amplitude of pineal melatonin secretion by a direct action on the circadian clock. Eur J Neurosci 16 1090-1098.

Burgess HJ, Revell VL, and Eastman CI (2008) A three pulse phase response curve to three milligrams of melatonin in humans. J Physiol 586:639-647.

Casida JE (1963) Mode of action of carbamates. Annu Rev Entomol 8:39-58.

Casida JE and Bryant RJ (2017) The ABCs of pesticide toxicology: amounts, biology, and chemistry. Toxicol Res (Camb) 6:755-763.

Cheng Y and Prusoff WH (1973) Relationship between the inhibition constant (K1) and the concentration of inhibitor which causes 50 per cent inhibition (I50) of an enzymatic reaction. Biochem Pharmacol 22:3099-3108.

Clark-Reyna SE, Grineski SE, and Collins TW (2016) Ambient concentrations of metabolic disrupting chemicals and children's academic achievement in El Paso, Texas. Int J Environ Res Public Health 13:574.

Declume C and Benard P (1977) Foetal accumulation of [14C] carbaryl in rats and mice. Autoradiographic study. Toxicology 8:95-105.

Dubocovich ML (2007) Melatonin receptors: role on sleep and circadian rhythm regulation. Sleep Med 8 (Suppl 3):34-42.

Dubocovich ML, Delagrange P, Krause DN, Sugden D, Cardinali DP, and Olcese J (2010) International Union of Basic and Clinical Pharmacology. LXXV. Nomenclature, classification, and pharmacology of G protein-coupled melatonin receptors Pharmacol Rev 62:343-380.

Dubocovich ML, Hudson RL, Sumaya IC, Masana MI, and Manna E (2005) Effect of MT1 melatonin receptor deletion on melatonin-mediated phase shift of circadian rhythms in the C57BL/6 mouse. J Pineal Res 39:113-120.

Dubocovich ML and Markowska M (2005) Functional MT1 and MT2 melatonin receptors in mammals. Endocrine 27:101-110.

Dubocovich ML, Yun K, Al-Ghoul WM, Benloucif S, and Masana MI (1998) Selective MT2 melatonin receptor antagonists block melatonin-mediated phase advances of circadian rhythms. FASEB J 12:1211-1220

Duggan RE, Corneliussen PE, Duggan MB, McMahon BM, and Martin RJ (1983) Pesticide residue levels in foods in the United States from July 1, 1969, to June 30, 1976: Summary. J Assoc Off Anal Chem 66:1534-1535.

Ecobichon DJ (2001) Pesticide use in developing countries. Toxicology 160:27-33.

Gartrell MJ, Craun JC, Podrebarac DS, and Gunderson EL (1985) Pesticides, selected elements, and other chemicals in adult total diet samples, October 1979September 1980. J Assoc Off Anal Chem 68:1184-1197.

Gartrell MJ, Craun JC, Podrebarac DS, and Gunderson EL (1986) Pesticides, selected elements, and other chemicals in adult total diet samples, October 1980March 1982. J Assoc Off Anal Chem 69:146-159.

Gerdin MJ, Masana MI, Ren D, Miller RJ, and Dubocovich ML (2003) Short-term exposure to melatonin differentially affects the functional sensitivity and trafficking of the hMT1 and hMT2 melatonin receptors. J Pharmacol Exp Ther $\mathbf{3 0 4}$ 931-939.

Gillette MU and Mitchell JW (2002) Signaling in the suprachiasmatic nucleus: selectively responsive and integrative. Cell Tissue Res 309:99-107.

Gunasekara AS, Rubin AL, Goh KS, Spurlock FC, and Tjeerdema RS (2008) Environmental fate and toxicology of carbaryl. Rev Environ Contam Toxicol 196 $95-121$.

Hunt AE, Al-Ghoul WM, Gillette MU, and Dubocovich ML (2001) Activation of MT(2) melatonin receptors in rat suprachiasmatic nucleus phase advances the circadian clock. Am J Physiol Cell Physiol 280:C110-C118.

Hutchinson AJ, Hudson RL, and Dubocovich ML (2012) Genetic deletion of MT(1) and MT(2) melatonin receptors differentially abrogates the development and expression of methamphetamine-induced locomotor sensitization during the day and the night in C3H/HeN mice. J Pineal Res 53:399-409.

Jablońska J and Brzeziński J (1990) The influence of carbaryl on the uptake of (3H)noradrenaline (3H)-NA by rat hypothalamic slices. Arch Toxicol 64:417-419.

Jockers R, Delagrange P, Dubocovich ML, Markus RP, Renault N, Tosini G, Cecon E, and Zlotos DP (2016) Update on melatonin receptors: IUPHAR Review 20. Br J Pharmacol 173:2702-2725.

Johansson LC, Stauch B, McCorvy JD, Han GW, Patel N, Huang XP, Batyuk A, Gati C, Slocum ST, Li C, et al. (2019) XFEL structures of the human $\mathrm{MT}_{2}$ melatonin receptor reveal the basis of subtype selectivity. Nature 569:289-292.

Karamitri A and Jockers R (2019) Melatonin in type 2 diabetes mellitus and obesity. Nat Rev Endocrinol 15:105-125.

Kavlock RJ, Austin CP, and Tice RR (2009) Toxicity testing in the 21st century: implications for human health risk assessment. Risk Anal 29:485-487; discussion 492-487.

Kenakin TP (2009) Pharmacological assay formats: binding, in A Pharmacology Primer (Kenakin TP ed), 3rd ed, pp 61-79, Academic Press, NY

Krolski ME, Nguyen T, Lopez R, YIng L-L, and Roensch W (2003) Metabolism and pharmacokinetics of [14C]-carbaryl in rats following mixed oral and dermal exposure. Bayer CropScience 169-0746.

Lacoste B, Angeloni D, Dominguez-Lopez S, Calderoni S, Mauro A, Fraschini F, Descarries L, and Gobbi G (2015) Anatomical and cellular localization of melatonin MT1 and MT2 receptors in the adult rat brain. J Pineal Res 58:397-417.

Lazareno S and Birdsall NJ (1995) Detection, quantitation, and verification of allosteric interactions of agents with labeled and unlabeled ligands at $\mathrm{G}$ proteincoupled receptors: interactions of strychnine and acetylcholine at muscarinic receptors. Mol Pharmacol 48:362-378.

Lebov JF, Engel LS, Richardson D, Hogan SL, Sandler DP, and Hoppin JA (2015) Pesticide exposure and end-stage renal disease risk among wives of pesticide applicators in the Agricultural Health Study. Environ Res 143:198-210.
Lefkowitz RJ, Mullikin D, and Caron MG (1976) Regulation of beta-adrenergic receptors by guanyl-5' - yl imidodiphosphate and other purine nucleotides. $J$ Biol Chem 251:4686-4692.

Legros C, Brasseur C, Delagrange P, Ducrot P, Nosjean O, and Boutin JA (2016) Alternative radioligands for investigating the molecular pharmacology of melatonin receptors. J Pharmacol Exp Ther 356:681-692.

Liu C and Gillette MU (1996) Cholinergic regulation of the suprachiasmatic nucleus circadian rhythm via a muscarinic mechanism at night. $J$ Neurosci 16 : $744-751$

Liu C, Weaver DR, Jin X, Shearman LP, Pieschl RL, Gribkoff VK, and Reppert SM (1997) Molecular dissection of two distinct actions of melatonin on the suprachiasmatic circadian clock. Neuron 19:91-102.

Liu J, Clough SJ, Hutchinson AJ, Adamah-Biassi EB, Popovska-Gorevski M, and Dubocovich ML (2016) MT1 and MT2 melatonin receptors: a therapeutic perspective. Annu Rev Pharmacol Toxicol 56:361-383.

Liu L, Labani N, Cecon E, and Jockers R (2019) Melatonin target proteins: too many or not enough? Front Endocrinol (Lausanne) 10:791.

Mahajan R, Blair A, Coble J, Lynch CF, Hoppin JA, Sandler DP, and Alavanja MC (2007) Carbaryl exposure and incident cancer in the Agricultural Health Study. Int $J$ Cancer 121:1799-1805.

Manyilizu WB, Mdegela RH, Kazwala R, Müller M, Lyche JL, and Skjerve E (2017) Self-reported health effects among short and long-term pesticide sprayers in Arusha, Northern Tanzania: a cross sectional study. Toxics 5:24

Masana MI, Benloucif S, and Dubocovich ML (2000) Circadian rhythm of mt1 melatonin receptor expression in the suprachiasmatic nucleus of the $\mathrm{C} 3 \mathrm{H} / \mathrm{HeN}$ mouse. $J$ Pineal Res 28:185-192.

Meeker JD, Ryan L, Barr DB, Herrick RF, Bennett DH, Bravo R, and Hauser R (2004) The relationship of urinary metabolites of carbaryl/naphthalene and chlorpyrifos with human semen quality. Environ Health Perspect 112:1665-1670.

Meyer A, Sandler DP, Beane Freeman LE, Hofmann JN, and Parks CG (2017) Pesticide exposure and risk of rheumatoid arthritis among licensed male pesticide applicators in the agricultural health study. Environ Health Perspect 125:077010.

Miller JA and Zahniser NR (1987) The use of 14C-labeled tissue paste standards for the calibration of 125I-labeled ligands in quantitative autoradiography. Neurosci Lett 81:345-350.

Montgomery MP, Kamel F, Saldana TM, Alavanja MC, and Sandler DP (2008) Incident diabetes and pesticide exposure among licensed pesticide applicators: $\mathrm{Ag}$ ricultural Health Study, 1993-2003. Am J Epidemiol 167:1235-1246.

Moser VC (1995) Comparisons of the acute effects of cholinesterase inhibitors using a neurobehavioral screening battery in rats. Neurotoxicol Teratol 17:617-625.

Moser VC, McCormick JP, Creason JP, and MacPhail RC (1988) Comparison of chlordimeform and carbaryl using a functional observational battery. Fundam Appl Toxicol 11:189-206.

Moser VC, Padilla S, Simmons JE, Haber LT, and Hertzberg RC (2012) Impact of chemical proportions on the acute neurotoxicity of a mixture of seven carbamates in preweanling and adult rats. Toxicol Sci 129:126-134.

Moser VC, Phillips PM, and McDaniel KL (2015a) Assessment of biochemical and behavioral effects of carbaryl and methomyl in Brown-Norway rats from preweaning to senescence. Toxicology 331:1-13.

Moser VC, Stewart N, Freeborn DL, Crooks J, MacMillan DK, Hedge JM, Wood CE McMahen RL, Strynar MJ, and Herr DW (2015b) Assessment of serum biomarker in rats after exposure to pesticides of different chemical classes. Toxicol Appl Pharmacol 282:161-174.

Nonno R, Lucini V, Pannacci M, Mazzucchelli C, Angeloni D, Fraschini F, and Stankov BM (1998) Pharmacological characterization of the human melatonin Mel1a receptor following stable transfection into NIH3T3 cells. Br J Pharmacol 124:485-492.

Pala D, Beuming T, Sherman W, Lodola A, Rivara S, and Mor M (2013a) Structurebased virtual screening of MT2 melatonin receptor: influence of template choice and structural refinement. J Chem Inf Model 53:821-835.

Pala D, Lodola A, Bedini A, Spadoni G, and Rivara S (2013b) Homology models of melatonin receptors: challenges and recent advances. Int J Mol Sci 14:8093-8121.

Patel O, Syamlal G, Henneberger PK, Alarcon WA, and Mazurek JM (2018) Pesticide use, allergic rhinitis, and asthma among US farm operators. J Agromed 23: $327-335$

Patel S and Sangeeta S (2019) Pesticides as the drivers of neuropsychotic diseases, cancers, and teratogenicity among agro-workers as well as general public. Environ Sci Pollut Res Int 26:91-100.

Peschke E, Bähr I, and Mühlbauer E (2013) Melatonin and pancreatic islets: interrelationships between melatonin, insulin and glucagon. Int $J \mathrm{Mol} S c i$ $6981-7015$

Popovska-Gorevski M, Dubocovich ML, and Rajnarayanan RV (2017) Carbamate insecticides target human melatonin receptors. Chem Res Toxicol 30:574-582.

Prosser RA, Dean RR, Edgar DM, Heller HC, and Miller JD (1993) Serotonin and the mammalian circadian system: I. In vitro phase shifts by serotonergic agonists and antagonists. J Biol Rhythms 8:1-16.

Rivara S, Lorenzi S, Mor M, Plazzi PV, Spadoni G, Bedini A, and Tarzia G (2005) Analysis of structure-activity relationships for MT2 selective antagonists by melatonin MT1 and MT2 receptor models. J Med Chem 48:4049-4060.

Ruppert PH, Cook LL, Dean KF, and Reiter LW (1983) Acute behavioral toxicity of carbaryl and propoxur in adult rats. Pharmacol Biochem Behav 18:579-584.

Saldana TM, Basso O, Hoppin JA, Baird DD, Knott C, Blair A, Alavanja MC, and Sandler DP (2007) Pesticide exposure and self-reported gestational diabetes mellitus in the Agricultural Health Study. Diabetes Care 30:529-534.

Schmidt CW (2009) TOX 21: new dimensions of toxicity testing. Environ Health Perspect 117:A348-A353.

Schroeder AM and Colwell CS (2013) How to fix a broken clock. Trends Pharmacol Sci 34:605-619.

Shealy DB, Barr JR, Ashley DL, Patterson DG Jr, Camann DE, and Bond AE (1997) Correlation of environmental carbaryl measurements with serum and urinary 
1-naphthol measurements in a farmer applicator and his family. Environ Health Perspect 105:510-513.

Siuciak JA, Fang JM, and Dubocovich ML (1990) Autoradiographic localization of 2 -[125I]iodomelatonin binding sites in the brains of $\mathrm{C} 3 \mathrm{H} / \mathrm{HeN}$ and $\mathrm{C} 57 \mathrm{BL} / 6 \mathrm{~J}$ strains of mice. Eur J Pharmacol 180:387-390.

Slager RE, Simpson SL, Levan TD, Poole JA, Sandler DP, and Hoppin JA (2010) Rhinitis associated with pesticide use among private pesticide applicators in the agricultural health study. J Toxicol Environ Health A 73:1382-1393.

Stauch B, Johansson LC, and Cherezov V (2020) Structural insights into melatonin receptors. FEBS J 287:1496-1510.

Stauch B, Johansson LC, McCorvy JD, Patel N, Han GW, Huang XP, Gati C, Batyuk A, Slocum ST, Ishchenko A, et al. (2019) Structural basis of ligand recognition at the human $\mathrm{MT}_{1}$ melatonin receptor. Nature 569:284-288.

Stein RM, Kang HJ, McCorvy JD, Glatfelter GC, Jones AJ, Che T, Slocum S, Huang XP, Savych O, Moroz YS, et al. (2020) Virtual discovery of melatonin receptor ligands to modulate circadian rhythms. Nature 579:609-614.

Sulkava S, Muggalla P, Sulkava R, Ollila HM, Peuralinna T, Myllykangas L, Kaivola $\mathrm{K}$, Stone DJ, Traynor BJ, Renton AE, et al. (2018) Melatonin receptor type 1A gene linked to Alzheimer's disease in old age. Sleep 41:zsy103.

Sulkava S, Ollila HM, Alasaari J, Puttonen S, Härmä M, Viitasalo K, Lahtinen A Lindström J, Toivola A, Sulkava R, et al. (2017) Common genetic variation near melatonin receptor $1 \mathrm{~A}$ gene linked to job-related exhaustion in shift workers. Sleep 40:zsw011.

Tice RR, Austin CP, Kavlock RJ, and Bucher JR (2013) Improving the human hazard characterization of chemicals: a Tox21 update. Environ Health Perspect 121: 756-765.

Tischkau SA, Jaeger CD, and Krager SL (2011) Circadian clock disruption in the mouse ovary in response to 2,3,7,8-tetrachlorodibenzo-p-dioxin. Toxicol Lett 201: $116-122$.

Tuomi T, Nagorny CLF, Singh P, Bennet H, Yu Q, Alenkvist I, Isomaa B, Östman B, Söderström J, Pesonen AK, et al. (2016) Increased melatonin signaling is a risk factor for type 2 diabetes. Cell Metab 23:1067-1077. van der Westhuizen ET, Valant C, Sexton PM, and Christopoulos A (2015) Endogenous allosteric modulators of G protein-coupled receptors. J Pharmacol Exp Ther 353:246-260. Wang HP, Liang YJ, Sun YJ, Hou WY, Chen JX, Long DX, Xu MY, and Wu YJ (2014) Subchronic neurotoxicity of chlorpyrifos, carbaryl, and their combination in rats. Environ Toxicol 29:1193-1200.

Whorton MD, Milby TH, Stubbs HA, Avashia BH, and Hull EQ (1979) Testicular function among carbaryl-exposed exployees. $J$ Toxicol Environ Health 5:929-941.

Wyrobek AJ, Watchmaker G, Gordon L, Wong K, Moore D II, and Whorton D (1981) Sperm shape abnormalities in carbaryl-exposed employees. Environ Health Perspect 40:255-265.

Xia Y, Cheng S, Bian Q, Xu L, Collins MD, Chang HC, Song L, Liu J, Wang S, and Wang X (2005) Genotoxic effects on spermatozoa of carbaryl-exposed workers. Toxicol Sci 85:615-623.

Xu C-X, Krager SL, Liao D-F, and Tischkau SA (2010) Disruption of CLOCK-BMAL1 transcriptional activity is responsible for aryl hydrocarbon receptor-mediated regulation of Period1 gene. Toxicol Sci 115:98-108.

Xu C-X, Wang C, Krager SL, Bottum KM, and Tischkau SA (2013) Aryl hydrocarbon receptor activation attenuates Per 1 gene induction and influences circadian clock resetting. Toxicol Sci 132:368-378.

Zheng T, Zahm SH, Cantor KP, Weisenburger DD, Zhang Y, and Blair A (2001) Agricultural exposure to carbamate pesticides and risk of non-Hodgkin lymphoma. J Occup Environ Med 43:641-649.

Zirlik S, Hildner KM, Targosz A, Neurath MF, Fuchs FS, Brzozowski T, and Konturek PC (2013) Melatonin and omentin: influence factors in the obstructive sleep apnoea syndrome? J Physiol Pharmacol 64:353-360.

Address correspondence to: Dr. Margarita L. Dubocovich, Department of Pharmacology and Toxicology, Jacobs School of Medicine and Biomedical Sciences, 955 Main St. (Room 3102), University at Buffalo (SUNY), Buffalo, NY 14203. E-mail: mdubo@buffalo.edu 